\title{
Life cycle environmental impacts of electricity from fossil fuels in Chile over a ten-year period
}

DOI:

10.1016/j.jclepro.2019.05.374

\section{Document Version}

Accepted author manuscript

Link to publication record in Manchester Research Explorer

\section{Citation for published version (APA):}

Gaete Morales, C., Gallego Schmid, A., Stamford, L., \& Azapagic, A. (2019). Life cycle environmental impacts of electricity from fossil fuels in Chile over a ten-year period. Journal of Cleaner Production.

https://doi.org/10.1016/j.jclepro.2019.05.374

\section{Published in:}

Journal of Cleaner Production

\section{Citing this paper}

Please note that where the full-text provided on Manchester Research Explorer is the Author Accepted Manuscript or Proof version this may differ from the final Published version. If citing, it is advised that you check and use the publisher's definitive version.

\section{General rights}

Copyright and moral rights for the publications made accessible in the Research Explorer are retained by the authors and/or other copyright owners and it is a condition of accessing publications that users recognise and abide by the legal requirements associated with these rights.

\section{Takedown policy}

If you believe that this document breaches copyright please refer to the University of Manchester's Takedown Procedures [http://man.ac.uk/04Y6Bo] or contact uml.scholarlycommunications@manchester.ac.uk providing relevant details, so we can investigate your claim.

\section{OPEN ACCESS}




\title{
Life cycle environmental impacts of electricity from fossil fuels
}

\section{in Chile over a ten-year period}

\author{
Carlos Gaete-Morales ${ }^{1,2}$, Alejandro Gallego-Schmid ${ }^{1,3}$, Laurence Stamford ${ }^{1}$ and Adisa Azapagic ${ }^{1} *$
}

${ }^{1}$ Sustainable Industrial Systems, School of Chemical Engineering and Analytical Science, University of Manchester, The Mill, Sackville Street, Manchester M13 9PL, UK.

${ }^{2}$ Department of Energy, Transportation and Environment, German Institute for Economic Research (DIW Berlin), Mohrenstraße 58, Berlin 10117, Germany.

3 Tyndall Centre for Climate Change Research, School of Mechanical, Aerospace and Civil Engineering, The University of Manchester, HG1, Pariser Building, Sackville Street, Manchester M13 9PL, UK.

* Corresponding author: adisa.azapagic@manchester.ac.uk

\begin{abstract}
This study uses life cycle assessment to evaluate the environmental impacts of electricity generated from fossil fuels in Chile over a ten-year period, from 2004-2014. The focus on fossil fuels is highly relevant for Chile because around $60 \%$ of electricity currently comes from natural gas, coal and oil. The impacts are first considered at the level of individual technologies, followed by the evaluation of the fossil-fuel electricity mix over the period. The study has been carried out using detailed primary data for 94 operating plants. Considering individual technologies, coal power has the worst performance for eight out of 11 impacts, with eutrophication, freshwater and marine ecotoxicity being between ten and 240 times greater than for gas. However, oil is worse than coal for photochemical oxidants (31\%) and depletion of elements and ozone layer (four and eight times, respectively). Between 2004 and 2014, the annual environmental impacts doubled, while electricity generation rose only by $55 \%$. The only exception to this is ozone depletion which fell by around $4 \%$. The highest impacts occurred in 2014 mainly because of the high contribution of coal power. Therefore, the environmental performance of fossil-based electricity in Chile has worsened over time due to the growing share of coal power, coupled with the increasing electricity demand. Consequently, policy should aim to increase the efficiency of power plants, avoid the use of petroleum coke, improve emissions control and replace coal and oil with gas power as soon as possible.
\end{abstract}

Keywords: Climate change; power generation; coal; oil; gas; life cycle assessment.

\section{INTRODUCTION}

Historically, the electricity in Chile was mainly supplied by hydropower (International Energy Agency, 2009). However, since the 90s, steady economic growth has led to an increase in electricity consumption, which has been growing by 7\% annually (Corbo and Hurtado, 2014). Consequently, electricity demand could no longer be covered only by new hydropower installations, but had to be supplemented by coal, natural gas and oil power (International Energy Agency, 2009, 2014; Raineri, 2006). As can be seen in Figure 1, this trend has continued over the years and nowadays the majority of electricity is generated from fossil fuels (60\%) (Bartos and Robertson, 2014; CNE, 2015a; Ministry of Energy of Chile, 2014a). In total, 94 power plants are in operation in Chile: 19 coal, four gas, 60 oil and 11 dual-fuel (oil and gas) installations. Their total installed capacity is $10.4 \mathrm{GW}$, comprising the following technologies (Figure 2): circulating fluidised bed (4\%), pulverised coal (36\%), combined cycle (32\%), open cycle (20\%) and diesel engine ( $8 \%)$.

In terms of electricity generation from fossil fuels, coal contributes $69 \%$, natural gas $24 \%$ and oil 7\% (CNE, 2015a). As Chile has low reserves of fossil fuels, the majority of fuels are imported (Bartos and Robertson, 2014; Ministry of Energy of Chile, 2014a). A growing number of studies are reporting a significant potential of renewable energies (PRIEN- 
UTFSM, 2008; Santana et al., 2014; Sims, 2011) which could gradually substitute fossil fuels. However, in the case of hydropower, which is still a significant contributor to power generation in Chile (34\%), the major difficulty in continuing its development is the social opposition (Bronfman et al., 2012). Therefore, the government is implementing measures for the deployment of other renewable energy sources, such as solar, wind and geothermal (Ministry of Energy of Chile, 2013, 2014b). However, the contribution of these technologies is still low ( 5\%) (Ministry of Energy of Chile, 2015). Therefore, in the medium term, fossil fuels will continue to contribute significantly to the electricity generation profile of Chile.

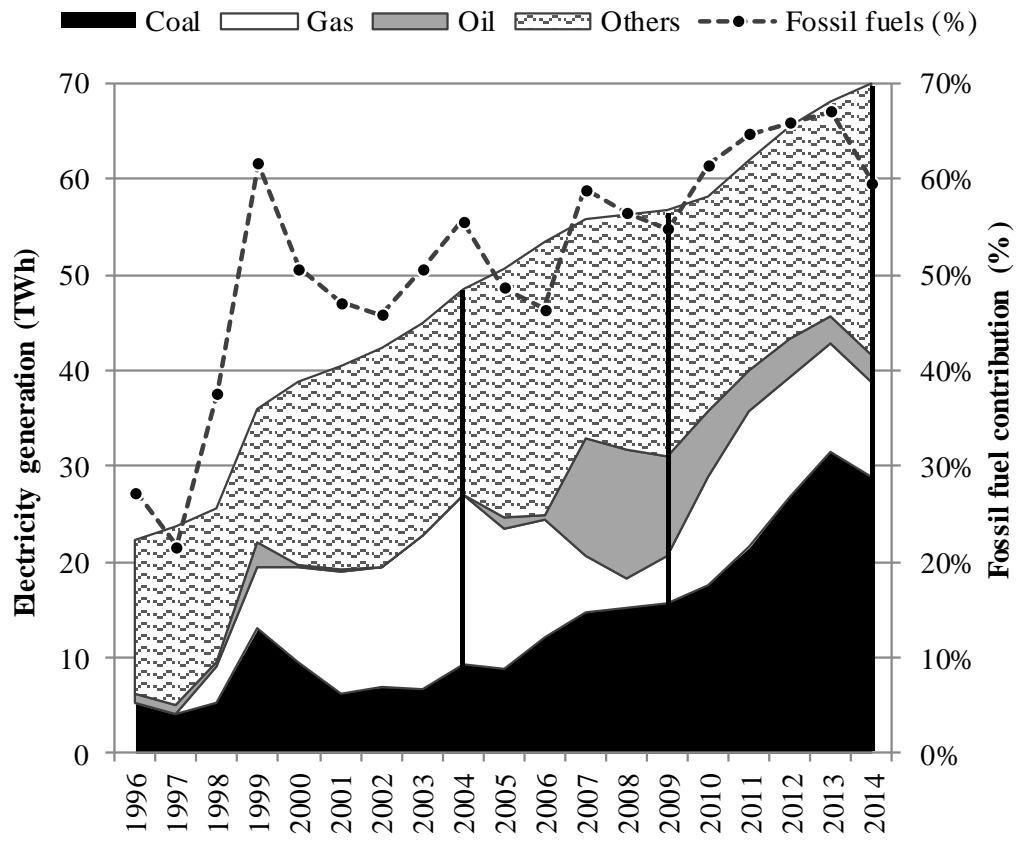

Figure 1. Electricity generation in Chile by source and contribution of fossil fuel in the period 1996-2014. [Vertical black lines denote the years chosen for the assessment in this study (2004, 2009 and 2014) (CISEN, 2016; CNE, 2015a)].

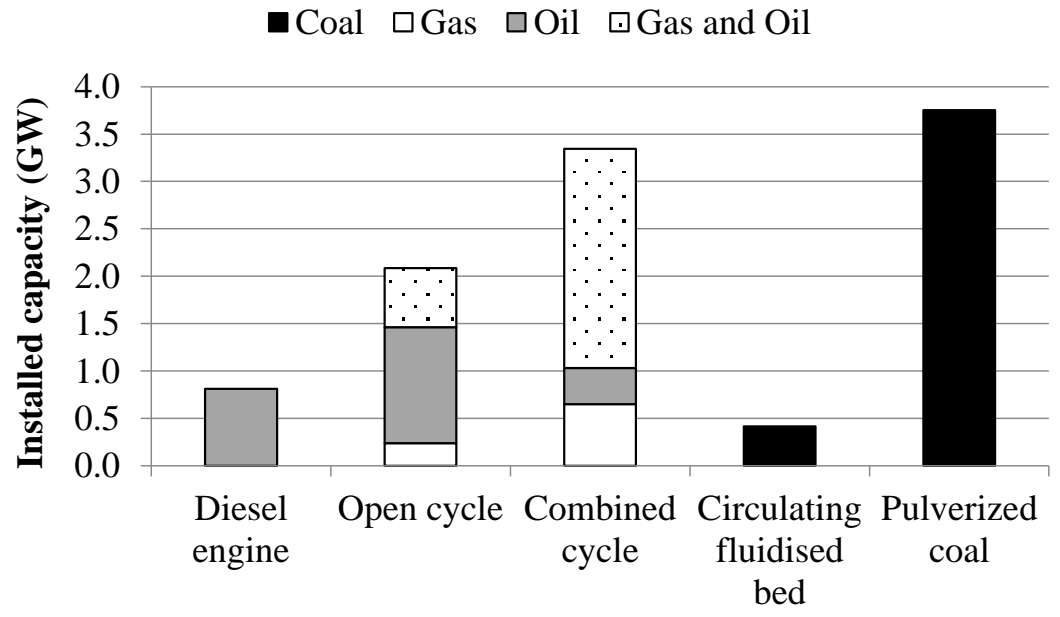

Figure 2. Current installed capacity in Chile by technology and fuel (CNE, 2015b).

Globally, electricity has been by far the most important source of anthropogenic $\mathrm{CO}_{2}$ emissions since the 1970s (UN Intergovernmental Panel on Climate Change, 2007) contributing to climate change, and Chile is no exception (International Energy Agency, 2009). As a result of a high contribution of fossil fuels to the electricity generation, the electricity sector emitted $30 \%$ of the total national greenhouse gas (GHG) emissions in 2010, equating to $27 \mathrm{Mt}$ of $\mathrm{CO}_{2}$ eq. (Ministry of Environment of Chile, 2014). This is equivalent to 
$0.09 \%$ of global GHG emissions. The Chilean government has committed to reducing GHG emissions per unit of GDP by $30 \%$ by 2030, relative to 2007 (Ministry of Environment of Chile, 2015). However, at present there is scant information on the contribution of fossil-fuel electricity to the GHG emissions on a life cycle basis, with other life cycle impacts being also largely unknown. Although two recent studies estimated life cycle impacts of electricity in Chile (Gaete-Morales et al., 2018; Vega-Coloma and Zaror, 2018), they both considered the whole electricity sector rather than focusing on the fossil-fuel sources. A similar situation is found for other countries, in which life cycle assessment studies (LCA) have been carried out for the whole sector (Garcia et al., 2014; Santoyo-Castelazo et al., 2011; Stamford and Azapagic, 2012). Therefore, this paper focuses of fossil-fuel power in Chile in an attempt to provide comprehensive information on its environmental impacts and inform policy. The impacts are estimated through LCA for each technology as well as for the fossil-fuel electricity mix. A temporal evolution of the impacts over a ten-year period (2004-2014) is also considered to determine how the impacts may have changed and why. The study relies on real data from the 94 plants currently operating in Chile. These are detailed in the next section, together with methods and assumptions used in the study.

\section{METHODS}

The LCA study has been carried out following the ISO 14040 and ISO 14044 standards (International Organization for Standardization, 2006a, 2006b), with the goal and scope defined next, followed by the inventory data and impacts considered in this work.

\subsection{Goal and scope definition}

The main goal of the study is to estimate the life cycle environmental impacts of fossil-fuel electricity generation in Chile in the period from 2004 to 2014. Two functional units are considered:

- $1 \mathrm{kWh}$ of electricity generated by coal, natural gas and oil power plants; and

- annual generation of electricity from these plants over the ten-year period.

As illustrated in Figure 3, the scope of the study is from 'cradle to grave'. The following stages are included: extraction, transport and processing of fossil fuels, power plant construction, operation and decommissioning, and end-of-life waste management. Transmission, distribution and use of electricity are outside the system boundaries as the focus is on generation.

\subsection{Inventory data and assumptions}

The study considers plants within two major electricity transmission systems in Chile: the Interconnected System of Norte Grande (SING) and Central Interconnected System (SIC). Collectively, these two systems supply $98 \%$ of national electricity consumption (CNE, 2015a).

Primary data have been sourced from the National Energy Commission (CNE), the Energy Ministry, National Service of Geology and Mining (SERNAGEOMIN), Environmental Protection Agency (SMA) and the SING and SIC load dispatch centres (CDEC-SING and CDEC-SIC). Additional information has been obtained from other institutional reports and academic literature as detailed below. The background data have been sourced from Ecoinvent 2.2 (Ecoinvent, 2010). These have been adapted to reflect Chilean conditions as follows:

- power plant combustion by using specific input flows and calorific values of fuels as well as the capacity factors and lifespans of the plants;

- power plant construction by adding the recycling rates at the end of life; and

- regional storage of fuel by adding input flows of each fuel-importing country and massweighted distances (t.km) for these countries. 


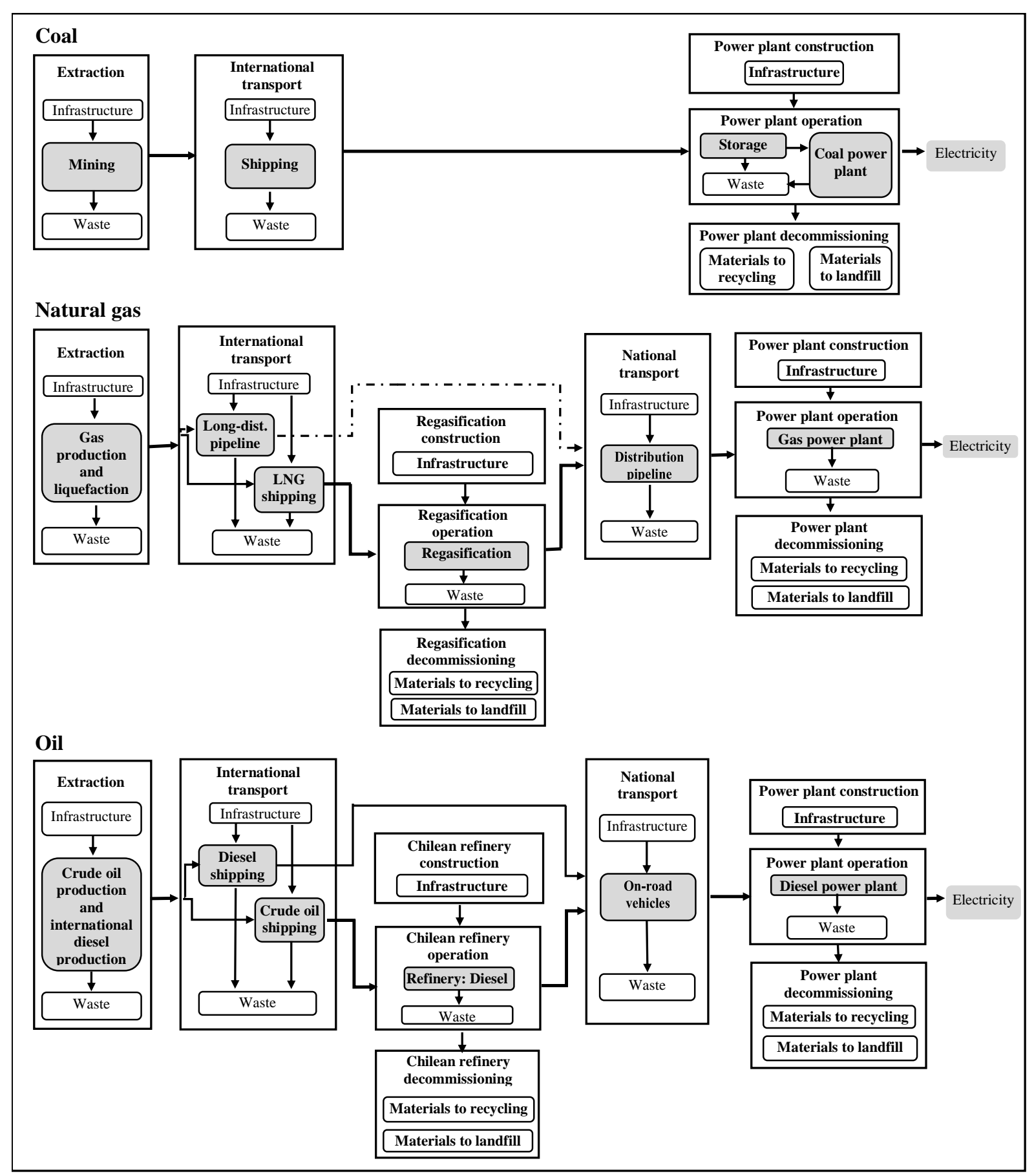

Figure 3. The life cycle of coal, gas and oil electricity from cradle to grave.

[Dashed lines represent processes that took place only in 2004. LNG: liquefied natural gas].

\subsubsection{Current situation: fuel supply and power plants}

The base year chosen for the study is 2014 , the most recent year for which detailed power plant data have been available. Total generation of fossil-based electricity in 2014 was 41,634 GWh, of which coal contributed $69 \%$, gas $24 \%$ and oil $7 \%$. Detailed data on the coal, gas and oil power plants are provided in Table 1-Table 3, while an overview of all data and assumptions can be found in Table 4. The following sections provide more detail on each type of fuel and the respective generating technologies. 


\subsubsection{Coal power plants}

Coal reserves in Chile are estimated at 1.2 bn $t$ of subbituminous coal located in the southernmost part of the country, the Magallanes region (Hackley et al., 2006). A coal mine came online in 2013 in that region, with a projected 12-year annual supply capacity of $6 \mathrm{Mt}$ (SEA, 2011). At present, this covers only 14\% of coal demand for electricity (Ministry of Energy of Chile, 2014a). The coal is shipped a distance of $3200 \mathrm{~km}$ to the coal power plants located in the north. The rest of the coal demand is covered through the imported bituminous coal: $54 \%$ from Colombia, 24\% from the US and $8 \%$ from Australia (CNE, 2015c).

Gross calorific value (CV) and composition of coal have been determined from 160 coal certificates of analysis (SMA, 2015), allowing the estimation of the average CV and coal composition by country of origin. In addition, two coal power plants used petroleum coke as secondary fuel imported from the US. One plant consumed petroleum coke as primary fuel; this plant is located in the refinery facilities in Chile and the petroleum coke is supplied by the refinery itself (ENAP, 2015). Each coal power plant has its own port and hence only the shipping between coal mines (Chilean, Colombia, US, Australia and Indonesian) and the coal power plants is considered.

The environmental burdens of petroleum coke have been obtained from Ecoinvent. As petroleum coke is co-produced with other products during crude-oil processing, allocation of the burdens has been carried out on a mass basis (Jungbluth, 2007).

Table 1. Coal power plants in Chile in the base year (CISEN, 2016; CNE, 2015a; Ministry of Energy of Chile, 2014a; SEA, 2015).

\begin{tabular}{|c|c|c|c|c|c|c|c|}
\hline & Power plant & Type $^{\mathrm{a}}$ & Emission control systems ${ }^{b}$ & $\begin{array}{c}\text { Installed } \\
\text { capacity } \\
(\mathrm{MW})\end{array}$ & $\begin{array}{c}\text { Electricity } \\
\text { generation } \\
(\mathrm{GWh})\end{array}$ & $\begin{array}{l}\text { Share } \\
(\%)\end{array}$ & $\begin{array}{c}\text { Efficiency } \\
(\%)\end{array}$ \\
\hline $\begin{array}{l}1 . \\
2 .\end{array}$ & $\begin{array}{l}\text { CTTAR } \\
\text { CTM1 - } 2\end{array}$ & $\begin{array}{l}\mathrm{PC} \\
\mathrm{PC}\end{array}$ & $\begin{array}{l}\text { ESP - BDC } \\
\text { ESP }\end{array}$ & $\begin{array}{l}158 \\
341\end{array}$ & $\begin{array}{c}911 \\
2,248\end{array}$ & $\begin{array}{l}3.2 \% \\
7.8 \%\end{array}$ & $\begin{array}{l}33 \% \\
34 \%\end{array}$ \\
\hline 3. & CTA & $\mathrm{CFB}$ & ESP - NOx (Limestone) & 169 & 1,044 & $3.6 \%$ & $36 \%$ \\
\hline 4. & $\mathrm{CTH}$ & CFB & ESP - NOx (Limestone) & 170 & 1,095 & $3.8 \%$ & $38 \%$ \\
\hline 5. & CTTO U12 - 13 & $\mathrm{PC}$ & ESP & 171 & 1,012 & $5.9 \%$ & $29 \%$ \\
\hline 6. & CTTO U14 - 15 & $\mathrm{PC}$ & ESP & 269 & 1,707 & $3.5 \%$ & $33 \%$ \\
\hline 7. & CT NTO1 & $\mathrm{PC}$ & ESP & 136 & 1,045 & $3.6 \%$ & $36 \%$ \\
\hline 8. & CT NTO2 & $\mathrm{PC}$ & - & 141 & 1,058 & $3.7 \%$ & $36 \%$ \\
\hline 9. & CT ANG1 - 2 & $\mathrm{PC}$ & ESP - SDA & 545 & 3,955 & $13.7 \%$ & $36 \%$ \\
\hline 10. & CT Santa María & $\mathrm{PC}$ & ESP - Wet scrubber - LowNOx & 370 & 2,623 & $9.1 \%$ & $41 \%$ \\
\hline & CT Bocamina I & $\mathrm{PC}$ & ESP & 130 & 5,08 & $1.8 \%$ & $39 \%$ \\
\hline 12. & CT Ventanas 1 & $\mathrm{PC}$ & ESP & 120 & 7,49 & $2.6 \%$ & $35 \%$ \\
\hline 13. & CT Ventanas 2 & $\mathrm{PC}$ & ESP - LowNOx & 220 & 1,178 & $4.1 \%$ & $36 \%$ \\
\hline 14. & CT N. Ventanas & $\mathrm{PC}$ & BDC - SDA - LowNOx & 272 & 2,183 & $7.6 \%$ & $35 \%$ \\
\hline 15. & CT Campiche & $\mathrm{PC}$ & BDC - SDA - LowNOx & 272 & 2,156 & $7.5 \%$ & $38 \%$ \\
\hline 16. & CT Guacolda $1-2^{c}$ & $\mathrm{PC}$ & ESP - BDC & 304 & 2,428 & $8.4 \%$ & $39 \%$ \\
\hline 17. & CT Guacolda $3^{\mathrm{c}}$ & $\mathrm{PC}$ & ESP - Wet scrubber - LowNOx & 152 & 1,216 & $4.2 \%$ & $39 \%$ \\
\hline 18. & CT Guacolda 4 & $\mathrm{PC}$ & ESP - LowNOx - SCR & 152 & 1,245 & $4.3 \%$ & $39 \%$ \\
\hline 19. & CT Petropower ${ }^{\mathrm{d}}$ & $\mathrm{CFB}$ & BDC - NOx (Limestone) & 75 & 530 & $1.8 \%$ & $29 \%$ \\
\hline
\end{tabular}

${ }^{\mathrm{a} P C}$ : Pulverised coal; CFB: Circulating fluidised bed.

${ }^{\mathrm{b}}$ ESP: Electrostatic precipitator; BDC: Baghouse dust collectors; SDA: Spray dryer absorber; Wet scrubber: desulphurisation system; LowNOx: Low NOx burner; SCR: Selective catalytic reduction.

${ }^{c}$ Petroleum coke used as secondary fuel.

${ }^{\mathrm{d}}$ Petroleum coke used as primary fuel. 
Table 2. Natural gas power plants in Chile in the base year (CISEN, 2016; CNE, 2015a; Ministry of Energy of Chile, 2014a; SEA, 2015).

\begin{tabular}{|c|c|c|c|c|c|c|c|}
\hline & Power plant ${ }^{\mathrm{a}}$ & Type $^{\text {b }}$ & Emission control systems ${ }^{c}$ & $\begin{array}{l}\text { Installed } \\
\text { capacity } \\
(\mathrm{MW})\end{array}$ & $\begin{array}{c}\text { Electricity } \\
\text { in } 2014 \\
(\mathrm{GWh}) \\
\end{array}$ & $\begin{array}{c}\text { Share } \\
(\%)\end{array}$ & $\begin{array}{c}\text { Efficiency } \\
(\%)\end{array}$ \\
\hline 1. & CTM3 & $\mathrm{CC}$ & LowNOx & 250 & 499 & $5 \%$ & $43 \%$ \\
\hline 2. & CTTO U16 & $\mathrm{CC}$ & - & 400 & 1,460 & $15 \%$ & $46 \%$ \\
\hline 3. & Gas Atacama 1 & $\mathrm{CC}$ & LowNOx & 389 & 28 & $<1 \%$ & $42 \%$ \\
\hline 4. & San Isidro I & $\mathrm{CC}$ & - & 379 & 1,751 & $18 \%$ & $45 \%$ \\
\hline 5. & San Isidro II & $\mathrm{CC}$ & - & 399 & 2,358 & $24 \%$ & $49 \%$ \\
\hline 6. & Nueva Renca & $\mathrm{CC}$ & SCR & 379 & 452 & $5 \%$ & $47 \%$ \\
\hline 7. & Nehuenco I & $\mathrm{CC}$ & Wet scrubber & 368 & 1,076 & $11 \%$ & $45 \%$ \\
\hline 8. & Nehuenco II & $\mathrm{CC}$ & Wet scrubber & 398 & 1,930 & $19 \%$ & $49 \%$ \\
\hline 9. & Nehuenco III & OC & Wet scrubber & 108 & 2 & $<1 \%$ & $28 \%$ \\
\hline 10. & Taltal 1 & OC & - & 123 & 77 & $1 \%$ & $29 \%$ \\
\hline 11. & Taltal 2 & $\mathrm{OC}$ & - & 122 & 114 & $1 \%$ & $29 \%$ \\
\hline 12. & Candelaria 1 & OC & Wet scrubber & 136 & 2 & $<1 \%$ & $28 \%$ \\
\hline 13. & Candelaria 2 & $\mathrm{OC}$ & Wet scrubber & 136 & 1 & $<1 \%$ & $28 \%$ \\
\hline 14. & Quintero A & $\mathrm{OC}$ & LowNOx & 120 & 97 & $1 \%$ & $28 \%$ \\
\hline 15. & Quintero B & $\mathrm{OC}$ & LowNOx & 120 & 150 & $1 \%$ & $28 \%$ \\
\hline
\end{tabular}

${ }^{\mathrm{a}}$ Power plants no. 3-13 also produce electricity from oil.

${ }^{\mathrm{b}} \mathrm{CC}$ : Combined cycle; OC: Open cycle.

${ }^{c}$ Wet scrubber: desulphurisation system; LowNOx: Low NOx burner; SCR: Selective catalytic reduction.

The majority of coal electricity is produced in pulverised coal plants, with only a small share generated in circulating fluidised bed installations (Figure 2). For the purposes of this study, all plants are assumed to use pulverised coal. The efficiencies of coal power plants have been obtained from $\mathrm{CNE}$ reports (CNE, 2015d, 2015e). Emissions of $\mathrm{CO}_{2}, \mathrm{SO}_{2}, \mathrm{NO}_{\mathrm{x}}$ and particulates from coal power plants have been obtained through direct emission measurements in power plants with continuous emissions monitoring systems (CEMS) (SMA, 2015); see Table 5.

\subsubsection{Natural gas power plants}

Chile covers about $20 \%$ of the total gas consumption with national reserves (Ministry of Energy of Chile, 2014a). The gas is produced in Magallanes region, but due to low production and geographical limitations for its distribution, it is just consumed by local communities. The remaining $80 \%$ of the gas demand is imported from Trinidad and Tobago as liquefied natural gas (LNG). LNG is shipped to Chile and processed in two regasification plants (CNE, 2015c). Once regasified, it is distributed through a pipeline network to the power plants. Currently, electricity generation from natural gas consumes $54 \%$ of natural gas imported (CISEN, 2016; CNE, 2015c, 2015a).

Both open and combined cycle plants are used for electricity generation from natural gas (Table 2). The efficiency of power plants has been estimated for each power plant based on the electricity produced and the amount of gas consumed (CISEN, 2016; CNE, 2015a); for details, see Table 2. Data for natural gas properties and composition are specific to LNG from Trinidad and Tobago (CNE, 2015c). Direct emissions of combined cycle plants have been estimated through CEMS records, whilst for open cycle plants, the emissions have been estimated using GEMIS 4.8 (International Institute for Sustainability Analysis and Strategy, 2015) due to a lack of primary data.

\subsubsection{Oil power plants}

Oil-fired power plants in Chile typically use diesel to produce electricity. Around $43 \%$ of the diesel is produced in Chile and the rest is imported from the US (CNE, 2015c; ENAP, 2015). Only 3\% of the diesel produced in Chile is from the domestic crude oil, with the majority imported from South American countries (84\%) and the UK (16\%) (CNE, 2015c; Ministry of Energy of Chile, 2014a). Chile's refineries are configured to produce $34 \%$ of diesel from 
crude oil processed (International Energy Agency, 2012; Superintendencia de Electricidad y Combustibles de Chile, 2014). Both crude oil and diesel are transported by tanker from exporting countries to Chile for further processing and diesel is subsequently transported to power plants by trucks. The diesel composition is based on data from a Chilean refinery (ENAP, 2015).

Oil power plants use open and combined cycle as well as diesel engine. Their efficiency and direct emissions have been determined in the same way as those of natural gas plants (Table $3)$. For combined cycle power plants, direct emissions have been obtained through CEMS records, and for open cycle turbines and diesel engines through modelling in GEMIS.

Like petroleum coke, environmental burdens of diesel have been sourced from Ecoinvent and allocated on a mass basis relative to the other refinery co-products (Jungbluth, 2007).

Table 3. Oil power plants in Chile in the base year (CISEN, 2016; CNE, 2015a; Ministry of Energy of Chile,

\begin{tabular}{|c|c|c|c|c|c|c|c|}
\hline & Power plant ${ }^{\mathrm{a}}$ & Type $^{b}$ & $\begin{array}{l}\text { Emission } \\
\text { control } \\
\text { systems }^{\mathrm{c}}\end{array}$ & $\begin{array}{c}\text { Installed } \\
\text { capacity } \\
(\mathrm{MW})\end{array}$ & $\begin{array}{c}\text { Electricity } \\
\text { in } 2014 \\
(\mathrm{GWh})\end{array}$ & $\begin{array}{c}\text { Share } \\
(\%)\end{array}$ & $\begin{array}{c}\text { Efficiency } \\
(\%)\end{array}$ \\
\hline & Gas Atacama 1 & $\mathrm{CC}$ & LowNOx & 389 & 320 & $12 \%$ & $41 \%$ \\
\hline & Gas Atacama 2 & $\mathrm{CC}$ & LowNOx & 383 & 558 & $20 \%$ & $42 \%$ \\
\hline & San Isidro I & $\mathrm{CC}$ & - & 379 & 21 & $1 \%$ & $43 \%$ \\
\hline & San Isidro II & $\mathrm{CC}$ & - & 399 & 39 & $1 \%$ & $46 \%$ \\
\hline & Nueva Renca & $\mathrm{CC}$ & SCR & 379 & 725 & $26 \%$ & $46 \%$ \\
\hline & Nehuenco I & $\mathrm{CC}$ & Wet scrubber & 368 & 233 & $8 \%$ & $50 \%$ \\
\hline & Nehuenco II & $\mathrm{CC}$ & Wet scrubber & 398 & 107 & $4 \%$ & $50 \%$ \\
\hline & Nehuenco III & OC & Wet scrubber & 108 & 5 & $<1 \%$ & $29 \%$ \\
\hline & Taltal 1 & $\mathrm{OC}$ & - & 123 & 7 & $<1 \%$ & $31 \%$ \\
\hline & Taltal 2 & OC & - & 122 & 1 & $<1 \%$ & $31 \%$ \\
\hline & Candelaria 1 & $\mathrm{OC}$ & Wet scrubber & 136 & 7 & $<1 \%$ & $29 \%$ \\
\hline & Candelaria 2 & $\mathrm{OC}$ & Wet scrubber & 136 & 6 & $<1 \%$ & $29 \%$ \\
\hline 13. & Rest of open cycle plants ( 24 plants $)^{\mathrm{d}}$ & $\mathrm{OC}$ & & 1220 & 350 & $13 \%$ & $35 \%$ \\
\hline 14. & Diesel engine plants (35 plants) ${ }^{\mathrm{d}}$ & $\mathrm{DE}$ & & 810 & 366 & $13 \%$ & $36 \%$ \\
\hline
\end{tabular}

${ }^{\mathrm{a}}$ Power plants no. 1-12 also generate electricity from natural gas.

${ }^{\mathrm{b}} \mathrm{CC}$ : Combined cycle; OC: Open cycle; DE: Diesel engine.

${ }^{c}$ Wet scrubber: desulphurisation system; LowNOx: Low NOx burner; SCR: Selective catalytic reduction

${ }^{\mathrm{d}} \mathrm{A}$ full list can be found in Table A1 in the Appendix.

\subsubsection{Previous years}

In addition to the base year (2014), electricity generation in years 2004 and 2009 is also considered. These two years have been chosen for the following reasons. The import of cheap natural gas from Argentina peaked in 2004, which also meant that the contribution of gas to electricity generation from fossil fuels peaked at $65 \%$ in that year. A progressive curtailment of the imports from Argentina then occurred between 2004 and 2008, which led to difficulties in 2009, when the electricity generation deficit had to be met with diesel. This increased the share of diesel to $33 \%$ of the total generation from fossil fuels. At the same time, the share of coal power grew from 35\% in 2004 to $51 \%$ in 2009. Due to the high cost of diesel, the prices of electricity increased significantly. To reduce the cost, the contribution from coal power plants continued to grow until 2014, exacerbated by a long-lasting drought which led to low generation from hydro plants (CISEN, 2016; Corbo and Hurtado, 2014; International Energy Agency, 2009). In summary, the contribution of different fuels to electricity from fossil fuels was as follows:

- 2004: coal 35\%; gas 65\%; oil 0\%;

- 2009: coal 51\%; gas 16\%; oil 33\%; and

- 2014: coal 69\%; gas 24\%; oil 7\%.

The assumptions and inventory data for 2004, 2009 and 2014 are given in Table 6 . 
Table 4. Assumptions and summary of inventory data for the base year (CISEN, 2016; CNE, 2015f, 2015a, 2015d, 2015c; CONAMA, 2010; Ecoinvent, 2010; ENAP, 2015; International Group of Liquefied Natural Gas Importers, 2015; Ministry of Energy of Chile, 2014a; Platts McGraw Hill Financial, 2015; SEA, 2015; SMA, 2015).

\begin{tabular}{|c|c|c|}
\hline Coal & Natural gas & Oil \\
\hline $\begin{array}{l}\text { Electricity generation by fuel } \\
\text { - Fossil fuels share: } 69 \% \\
\text { - Plant type: pulverised coal } \\
\text { - } \eta^{\mathrm{a}}: 36 \%, \mathrm{CF}^{\mathrm{b}}: 81 \% \\
\text { - For details, see Table } 1\end{array}$ & $\begin{array}{l}\text { - Fossil fuels share: } 24 \% \\
\text { - Plant type: } \mathrm{CC}^{\mathrm{c}} \text { and } \mathrm{OC}^{4} \\
\text { - } \mathrm{CC}^{\mathrm{c}} \text { share: } 96 \%, \eta^{\mathrm{a}}: 47 \%, \mathrm{CF}^{\mathrm{b}}: 53 \% \\
\text { - OC } \mathrm{OC}^{\mathrm{d}} \text { power share: } 4 \%, \eta^{\mathrm{a}}: 28 \%, \mathrm{CF}^{\mathrm{b}} \text { : } \\
11 \% \\
\text { - For details, see Table } 2\end{array}$ & $\begin{array}{l}\text { - Fossil fuels share: } 7 \% \\
\text { - Plant type: } \mathrm{CC}^{\mathrm{c}}, \mathrm{OC}^{\mathrm{d}} \text { and } \mathrm{DE}^{\mathrm{e}} \\
\text { - } \mathrm{CC}^{\mathrm{c}} \text { share: } 73 \%, \eta^{\mathrm{a}}: 44 \%, \mathrm{CF}^{\mathrm{b}}: 15 \% \\
\text { - } \mathrm{OC}^{\mathrm{d}} \text { power share: } 14 \%, \eta^{\mathrm{a}}: 34 \%, \mathrm{CF}^{\mathrm{b}}: 6 \% \\
\text { - } \mathrm{DE}^{\mathrm{e}} \text { power share: } 13 \%, \eta^{\mathrm{a}}: 36 \%, \mathrm{CF}^{\mathrm{b}}: 8 \% \\
\text { - For details, see Table } 3\end{array}$ \\
\hline \multicolumn{3}{|l|}{ Plant construction } \\
\hline - Lifetime: 38 years & - Lifetime: 35 years & $\begin{array}{l}\text { - Lifetime: } 35 \text { years. Plants with lower } \\
\text { capacity factors: } 45 \text { years }\end{array}$ \\
\hline $\begin{array}{l}\text { - Data from Ecoinvent based on } \\
\text { average size of the plant of } \\
460 \mathrm{MW}\end{array}$ & $\begin{array}{l}\text { - Data from Ecoinvent based on average } \\
\text { plant size of } 400 \mathrm{MW} \text { and } 100 \mathrm{MW} \text { for } \\
\mathrm{CC}^{\mathrm{c}} \text { and } \mathrm{OC}^{\mathrm{d}} \text {, respectively }\end{array}$ & $\begin{array}{l}\text { - Data from Ecoinvent based on average } \\
\text { plant size of } 400 \mathrm{MW}, 100 \mathrm{MW} \text { and } 10 \\
\text { MW for } \mathrm{CC}^{\mathrm{c}}, \mathrm{OC}^{\mathrm{d}} \text { and } \mathrm{DE}^{\mathrm{e}} \text {, respectively }\end{array}$ \\
\hline
\end{tabular}

Plant decommissioning

- Steel: $93 \%$ recycled. Aluminium: $43 \%$ recycled. Copper: 50\% recycled. The system is credited for recycled materials

- Concrete and plastics are not recycled. Materials not recycled are disposed in landfills

Fuel extraction and processing

- Coal: $10.7 \mathrm{Mt} / \mathrm{yr}$

- Contribution, $\mathrm{CV}^{\mathrm{f}}$ :

Chile: $14 \%, 18.9 \mathrm{MJ} / \mathrm{kg}$

Colombia: $54 \%, 26.8 \mathrm{MJ} / \mathrm{kg}$

US: $24 \%, 26.0 \mathrm{MJ} / \mathrm{kg}$

Australia: $8 \%, 27.0 \mathrm{MJ} / \mathrm{kg}$

- Petroleum coke: $473 \mathrm{kt}$

- Contribution, $\mathrm{CV}^{\mathrm{f}}$ :

Chile: $42 \%, 32.5 \mathrm{MJ} / \mathrm{kg}$

US: $58 \%, 32.5 \mathrm{MJ} / \mathrm{kg}$

- Coal composition:

(as received)

Carbon: $57.5 \%$

Hydrogen: $4.4 \%$

Sulphur: $0.7 \%$

Oxygen: $12.5 \%$

Nitrogen: $1.2 \%$

Ash: 9.7\%

Water: $14.0 \%$

Chlorine: $130 \mathrm{ppm}$

Fluor: $10 \mathrm{ppm}$

- Density: $920 \mathrm{~kg} / \mathrm{m}^{3}$

- Natural gas: 1,923 $\mathrm{MNm}^{3} / \mathrm{yr}$

- Contribution, $\mathrm{CV}^{\mathrm{f}}$ :

$\mathrm{LNG}^{\mathrm{g}}: 100 \%, 41.1 \mathrm{MJ} / \mathrm{Nm}^{3}$

Long-dist. pipeline: $0 \%, 39.1 \mathrm{MJ} / \mathrm{Nm}^{3}$

- Quintero regasification plant capacity: $5,475 \mathrm{MNm}^{3}$

- Data from Ecoinvent based on evaporation plant of average size of 42,300 $\mathrm{MNm}^{3} / \mathrm{yr}$

- Natural gas sales in Chile in 2014 accounted to $3,317 \mathrm{MNm}^{3}$ processed at two terminals and distributed through $836 \mathrm{~km}$ of pipelines

- Natural gas composition:

Methane C1: $96.78 \%$

Ethane C2: $2.78 \%$

Propane C3: $0.37 \%$

Butane C4+: 0.06\%

Nitrogen: $0.01 \%$

- LNG $^{\mathrm{g}}$ density: $431.03 \mathrm{~kg} / \mathrm{m}^{3}$

- Gas density: $0.74 \mathrm{~kg} / \mathrm{Nm}^{3}$

\section{Transport}

- Distance by ship

Chile: 3,220 km

Colombia: $4,585 \mathrm{~km}$

US: $8,785 \mathrm{~km}$

Australia: $11,959 \mathrm{~km}$
- Distance

$\mathrm{LNG}^{\mathrm{g}}$ : $12,684 \mathrm{~km}$

Long-distance pipeline: $558 \mathrm{~km}$
- Diesel: 523 kt/yr

- Contribution:

Chile (refinery): $43 \%$

US (import): $57 \%$

- $\mathrm{CV}^{\mathrm{f}}: 45.6 \mathrm{MJ} / \mathrm{kg}$

- Crude oil with destination to refinery South America: 84\% (Chile:3.6\%) UK: $16 \%$

- Chilean refinery produce $34 \%$ of diesel from crude oil processed

- Diesel composition: Carbon: $86.1 \%$ Hydrogen: $13.5 \%$ Sulphur: $0.4 \%$ - Density: 0.84 t/m

${ }^{a} \eta$ : Power plant efficiency.

${ }^{b} \mathrm{CF}$ : Capacity factor. As capacity factors of power plants can vary significantly year by year, an average capacity factor over the past three years has been estimated for each power plant; see the Appendix.

${ }^{\mathrm{c}} \mathrm{CC}$ : Combined cycle power plant.

${ }^{\mathrm{d} O C}$ : Open cycle power plant.

e DE: Diesel engine power plant.

${ }^{\mathrm{f}} \mathrm{CV}$ : Gross calorific value.

${ }^{\mathrm{g}} \mathrm{LNG}$ : Liquefied natural gas. 
Table 5. Emission factors for coal, natural gas and oil power plants by technology ${ }^{\mathrm{a}}$ (International Institute for Sustainability Analysis and Strategy, 2015; SMA, 2015).

\begin{tabular}{|c|c|c|c|c|c|c|}
\hline & Coal plants & Natural gas plar & & Oil plants & & \\
\hline Emissions & $\begin{array}{l}\text { Pulverised } \\
\text { coal }^{\mathrm{a}}\left(\mathrm{g} / \mathrm{MJ}_{\mathrm{in}}\right)\end{array}$ & $\begin{array}{l}\text { Combined } \\
\text { cycle }^{\mathrm{a}}\left(\mathrm{g} / \mathrm{MJ}_{\mathrm{in}}\right)\end{array}$ & $\begin{array}{l}\text { Open cycle } \\
\left(\mathrm{g} / \mathrm{MJ}_{\text {in }}\right)\end{array}$ & $\begin{array}{l}\text { Combined } \\
\text { cycle }^{\mathrm{a}}\left(\mathrm{g} / \mathrm{MJ}_{\text {in }}\right)\end{array}$ & $\begin{array}{l}\text { Open cycle } \\
\left(\mathrm{g} / \mathrm{MJ}_{\mathrm{in}}\right)\end{array}$ & $\begin{array}{l}\begin{array}{l}\text { Diesel engine } \\
\mathrm{b} \\
\left(\mathrm{g} / \mathrm{MJ}_{\text {in }}\right)\end{array} \\
\end{array}$ \\
\hline $\mathrm{CO}_{2}$ & 97.5 & 61.9 & 56.1 & 88.9 & 80.5 & 75.9 \\
\hline NOx & 0.167 & 0.129 & 0.025 & 0.295 & 0.265 & 0.829 \\
\hline $\mathrm{SO}_{2}$ & 0.337 & 0.001 & 0.001 & 0.185 & 0.474 & 0.192 \\
\hline Particles & 0.007 & - & - & - & - & - \\
\hline
\end{tabular}

Table 6. Inventory data for fossil-based electricity in Chile in 2004, 2009 and 2014.

\begin{tabular}{|c|c|c|c|c|}
\hline Category & Description (unit) & 2004 & 2009 & 2014 \\
\hline \multirow[t]{4}{*}{ General } & Total electricity generation $(\mathrm{GWh} / \mathrm{yr})$ & 26,912 & 31,051 & 41,634 \\
\hline & Contribution of coal $(\%)$ & $35 \%$ & $51 \%$ & $69 \%$ \\
\hline & Contribution of natural gas (\%) & $65 \%$ & $16 \%$ & $24 \%$ \\
\hline & Contribution of oil (\%) & $0 \%$ & $33 \%$ & $7 \%$ \\
\hline \multirow[t]{21}{*}{ Coal } & Pulverised coal plant efficiency (\%) & $35 \%$ & $36 \%$ & $36 \%$ \\
\hline & Coal consumption (1000s t) & 3,601 & 4,870 & 10,742 \\
\hline & Coal from Chile (\%) & $5 \%$ & $11 \%$ & $14 \%$ \\
\hline & Coal from Colombia (\%) & $17 \%$ & $66 \%$ & $54 \%$ \\
\hline & Coal from Indonesia (\%) & $23 \%$ & $10 \%$ & $0 \%$ \\
\hline & Coal from US $(\%)$ & $23 \%$ & $11 \%$ & $24 \%$ \\
\hline & Coal from Australia (\%) & $32 \%$ & $2 \%$ & $8 \%$ \\
\hline & Consumption of petroleum coke (1000s t) & 720 & 1,289 & 473 \\
\hline & Petroleum coke from Chile $(\%)$ & $19 \%$ & $68 \%$ & $42 \%$ \\
\hline & Petroleum coke from US (\%) & $81 \%$ & $32 \%$ & $58 \%$ \\
\hline & Gross calorific value of coal from Australia (MJ/kg) & 21.0 & 25.0 & 27.0 \\
\hline & Gross calorific value of coal from Chile (MJ/kg) & 18.9 & 18.9 & 18.9 \\
\hline & Gross calorific value of coal from Colombia $(\mathrm{MJ} / \mathrm{kg})$ & 21.0 & 25.0 & 26.8 \\
\hline & Gross calorific value of coal from Indonesia $(\mathrm{MJ} / \mathrm{kg})$ & 21.0 & 25.0 & 20.7 \\
\hline & Gross calorific value of coal from US (MJ/kg) & 21.0 & 25.0 & 26.0 \\
\hline & Gross calorific value of petroleum coke $(\mathrm{MJ} / \mathrm{kg})$ & 32.5 & 32.5 & 32.5 \\
\hline & Distance from Australia (km) & 11,959 & 11,959 & 11,959 \\
\hline & Distance in Chile (mine to power plant) $(\mathrm{km})$ & 3,220 & 3,220 & 3,220 \\
\hline & Distance from Colombia $(\mathrm{km})$ & 4,585 & 4,585 & 4,585 \\
\hline & Distance from Indonesia $(\mathrm{km})$ & 11,959 & 11,959 & 11,959 \\
\hline & Distance from US $(\mathrm{km})$ & 8,785 & 8,785 & 8,785 \\
\hline \multirow[t]{8}{*}{ Natural gas } & Contribution of combined cycle plants (\%) & $100 \%$ & $100 \%$ & $96 \%$ \\
\hline & Contribution of open cycle plants (\%) & $0 \%$ & $0 \%$ & $4 \%$ \\
\hline & Combined cycle plant efficiency $(\%)$ & $47 \%$ & $48 \%$ & $47 \%$ \\
\hline & Open cycle plant efficiency $(\%)$ & $28 \%$ & $28 \%$ & $28 \%$ \\
\hline & Natural gas consumption $\left(\mathrm{MNm}^{3}\right)$ & 3,453 & 920 & 1,923 \\
\hline & Liquefied natural gas $(\%)$ & $0 \%$ & $42 \%$ & $100 \%$ \\
\hline & Natural gas from Argentina (\%) & $100 \%$ & $58 \%$ & $0 \%$ \\
\hline & Gross calorific value of gas $\left(\mathrm{MJ} / \mathrm{Nm}^{3}\right)$ & 39.1 & 39.9 & 41.1 \\
\hline \multirow[t]{15}{*}{ Oil } & Contribution of combined cycle plants (\%) & - & $81 \%$ & $73 \%$ \\
\hline & Contribution of diesel engine plants (\%) & - & $9 \%$ & $13 \%$ \\
\hline & Contribution of open cycle plants $(\%)$ & - & $10 \%$ & $14 \%$ \\
\hline & Combined cycle plant efficiency $(\%)$ & - & $44 \%$ & $44 \%$ \\
\hline & Diesel engine plant efficiency $(\%)$ & - & $36 \%$ & $36 \%$ \\
\hline & Open cycle plant efficiency (\%) & - & $34 \%$ & $34 \%$ \\
\hline & Diesel consumption $(1000 \mathrm{~s} t)$ & - & 1,959 & 523 \\
\hline & Diesel from Chile $(\%)$ & - & $45 \%$ & $43 \%$ \\
\hline & Diesel from US (\%) & - & $0 \%$ & $57 \%$ \\
\hline & Diesel from Korea and Japan (\%) & - & $55 \%$ & $0 \%$ \\
\hline & Distance from US (km) & - & - & 8,785 \\
\hline & Distance from Korea and Japan $(\mathrm{km})$ & - & 18,838 & - \\
\hline & Crude oil from Latin America refined in Chile (\%) & - & $84 \%$ & $84 \%$ \\
\hline & Crude oil from UK refined in Chile $(\%)$ & - & $16 \%$ & $16 \%$ \\
\hline & Gross calorific value of oil (MJ/kg) & - & 45.6 & 45.6 \\
\hline
\end{tabular}




\subsection{Impact assessment}

The power systems have been modelled using Gabi v6.0 (PE International, 2013). The following 11 environmental impacts are considered, estimated according to the CML 2001 method (April 2015 update) (Guinée et al., 2002): abiotic depletion potential of fossil resources $\left(\mathrm{ADP}_{\text {fossil }}\right)$, abiotic depletion potential of elements $\left(\mathrm{ADP}_{\text {elements }}\right)$, eutrophication potential (EP), freshwater aquatic ecotoxicity potential (FAETP), global warming potential (GWP), human toxicity potential (HTP), marine aquatic ecotoxicity potential (MAETP), ozone layer depletion potential (ODP, steady state), photochemical oxidants creation potential (POCP), and terrestrial ecotoxicity potential (TETP). The CML methodology has been chosen to maximise comparability with prior literature on fossil-based electricity technologies in other countries, ensuring that the LCA results for Chile can be contextualised and compared with those (see Section 3.1.12).

\section{RESULTS AND DISCUSSION}

This section discusses first the impact per $\mathrm{kWh}$ of electricity generated, followed by the evolution of impacts over the ten-year period in section 3.2.

\subsection{Environmental impacts of fossil-fuel technologies}

The environmental impacts of electricity from coal, gas and oil, expressed per $\mathrm{kWh}$ and showing the contribution of different life cycle stages, are summarised Figure 4. These results refer to the base year (2014). As can be seen, electricity generation from gas has the lowest impacts across all the impact categories. Coal is the worst option overall, with the highest values in eight out of 11 impact categories considered. For example, if compared with oil, coal has around 20\% higher GWP and AP, four times greater HTP and 45 times higher MAETP. However, oil performs worse than coal in three impacts - POCP, ADP elements and ODP - which are $31 \%$, four and eight times higher than for coal, respectively.

The majority of the impacts are mainly due to the extraction of fossil fuels and operation of power plants. The construction and decommissioning of the plants are only significant for $\mathrm{ADP}_{\text {elements }}$ which can be reduced by $9 \%-21 \%$ across the options through recycling. These results are discussed in more detail below. Note that the total impacts incorporate the credits for material recycling while the contributions of different life cycle stages are estimated before applying the credits.

\subsubsection{Abiotic depletion potential of fossil resources $\left(A D P_{\text {fossil }}\right)$}

Electricity generation from coal and oil have similar values for depletion of fossil resources (10.3 and $10.1 \mathrm{MJ} / \mathrm{kWh}$, respectively) while the impact for gas is somewhat lower (9 $\mathrm{MJ} / \mathrm{kWh}$ ). These differences are associated with the efficiency of plants and calorific values of the fuels, both of which are highest for gas. Extraction of fuels is the main contributor with a share of $96 \%$ for coal and $90 \%$ for gas and oil. The rest is related to transport, and in the case of oil, also to processing $(5 \%)$.

\subsubsection{Abiotic depletion potential of elements $\left(A D P_{\text {elements }}\right)$}

Oil power leads to the highest depletion of elements (123 $\mu \mathrm{g} \mathrm{Sb}$ eq./kwh), which is four times higher than coal $(30 \mu \mathrm{g} \mathrm{Sb}$ eq./kWh) and five times greater than gas $(24 \mu \mathrm{g} \mathrm{Sb}$ eq./kWh). The high impact from oil is largely related to the lorry transport between the refineries and power plants. Gold and lead are the main elements depleted, associated with gold content in electronic parts of the vehicle and the use of lead for vehicle batteries (Spielmann et al., 2007). 


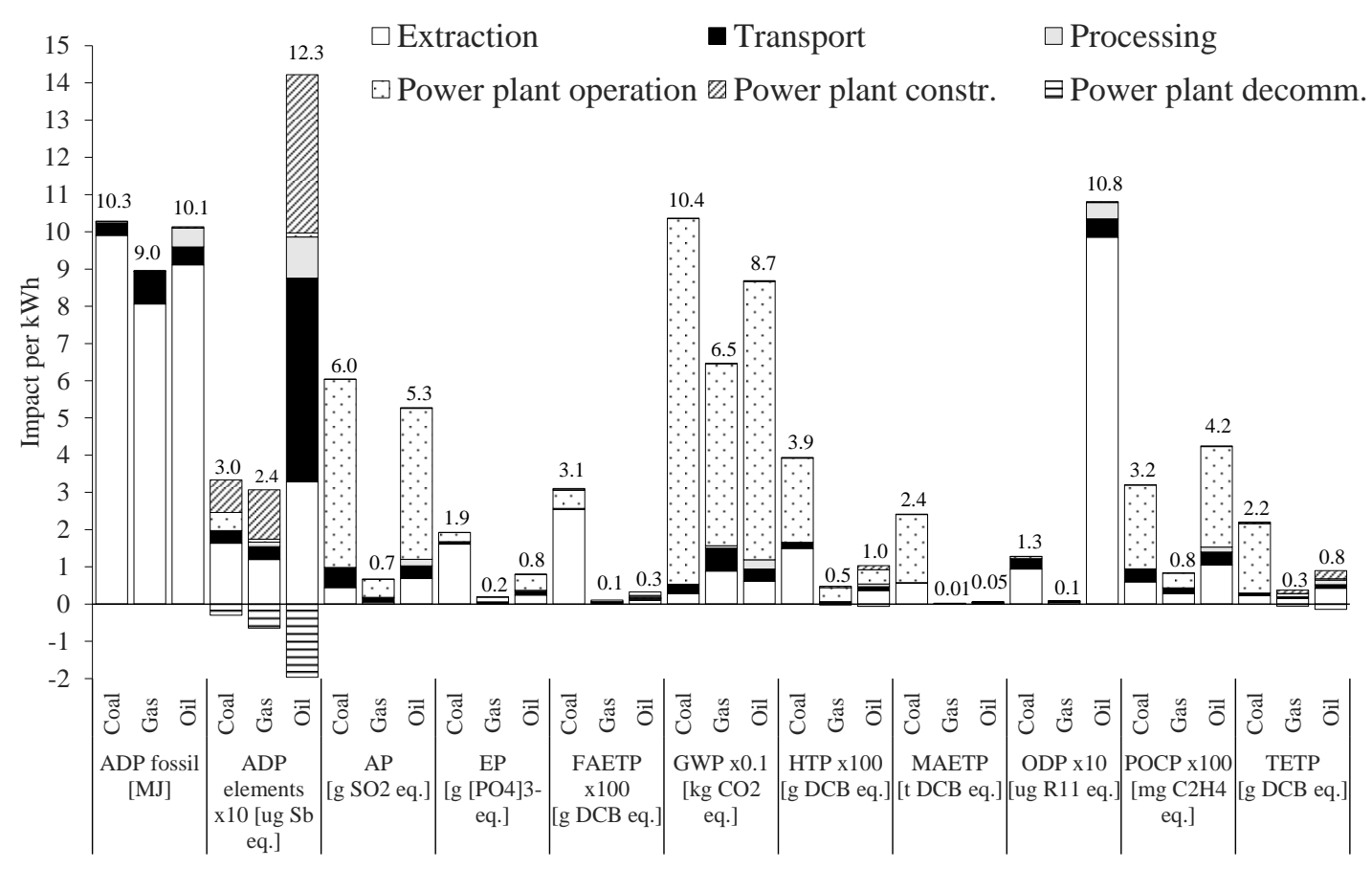

Figure 4. Environmental impact per kWh of electricity for the base year (2014).

[Values shown on top of each bar represent the net impacts, including the recycling credits. The scaled impacts should be multiplied by the factor shown in brackets for relevant categories. ADP: abiotic depletion potential, AP: acidification potential, EP: eutrophication potential, FAETP: freshwater aquatic ecotoxicity potential, GWP: global warming potential, HTP: human toxicity potential, MAETP: marine aquatic ecotoxicity potential, ODP: ozone depletion potential, POCP: photochemical oxidants creation potential, TETP: terrestrial ecotoxicity potential].

Fuel extraction contributes $48 \%$ to coal and $40 \%$ to gas power (before the credits for recycling). The contribution from construction is also significant: $43 \%$ for gas and $\sim 30 \%$ for coal and oil plants (all before the system credits). The high contribution of construction is attributed to the use of scarce materials within power plants and their equipment. Therefore, the recycling rates as well as the capacity factors of power plants are significant factors. For example, electricity from gas and oil is mostly produced in combined cycle plants, which contain scarce elements, such as chromium and copper. In addition, oil power is a peak-load technology, leading to a low capacity factor of $15 \%$, and therefore the depletion due to construction is relatively high per unit of electricity generated. For coal power, the main cause of this impact are copper, gold, molybdenum, zinc and chromium used for explosives and metals in the mine infrastructure (Dones et al., 2007). The recycling of copper and steel, as part of the decommissioning stage, reduces the impact across the three options by $9 \%$ for coal, $21 \%$ for gas and $14 \%$ for oil.

\subsubsection{Acidification potential (AP)}

Coal and oil have an order of magnitude higher AP than gas: 6 and 5.3 vs $0.7 \mathrm{~g} \mathrm{SO}_{2}$ eq./kWh, respectively. The combustion of fuel to produce electricity is the most important process for this impact with a contribution of $84 \%$ for coal, $77 \%$ for oil and $73 \%$ for gas. Coal combustion has the highest impact because of higher emission factors (Table 5) and the lowest efficiency among the fossil fuel plants. It can also be noted that oil has a much higher impact than gas despite both fuels being predominantly used in high efficiency combined cycle plants. This is due to the $\mathrm{SO}_{2}$ emissions from oil being 185 times higher than for gas, related to the sulphur content in oil of $0.4 \%$. Furthermore, $13 \%$ of oil-fired power generation occurs in diesel engines which have $\mathrm{NO}_{\mathrm{x}}$ emissions about five times higher than typical coal and gas plants. This explains why oil power, in spite of a higher efficiency (42\%), has a higher AP. 


\subsubsection{Eutrophication potential (EP)}

At $1.9 \mathrm{~g} \mathrm{PO}_{4}{ }^{3-}$ eq./kWh, coal has the highest $\mathrm{EP}$, double that of oil $\left(0.8 \mathrm{~g} \mathrm{PO}_{4}{ }^{3-} \mathrm{eq.} / \mathrm{kWh}\right)$ and ten times higher than gas $\left(0.2 \mathrm{~g} \mathrm{PO}_{4}{ }^{3-} \mathrm{eq} . / \mathrm{kWh}\right)$. This is mainly due to mining $(84 \%)$, related to the release of significant amounts of phosphate to freshwater (Dones et al., 2007). The higher impact of coal compared to the other two options is also compounded by its lower calorific value and efficiency of the power plants, both of which increase the demand for coal per unit of electricity generated. In relation to coal mining, there are significant differences among mines in terms of environmental burdens and energy content of coal. For example, coal from Australia has 4.7 times higher environmental burdens than that from South America because Australian coal beds are typically deeper and require more energy for excavation (Dones et al., 2007; Ecoinvent, 2010). Therefore, the Australian coal causes 22\% of the EP attributable to extraction, despite its contribution to the imported-coal mix of only $8 \%$. By contrast, fuel combustion in power plants is the main contributor to the impact from gas $(68 \%)$ and oil power (53\%). For coal, its contribution is much lower (12\%) due to a high contribution from mining compared to the other two fuels. $\mathrm{NO}_{\mathrm{x}}$ emissions are the main cause of EP for all the power plants.

\subsubsection{Freshwater aquatic ecotoxicity potential (FAETP)}

Coal power is again the worst option for this impact (310 g DCB eq./kWh), with a value ten times higher than for oil (32 g DCB eq./kWh) and 28 times higher than for gas $(11 \mathrm{~g}$ DCB eq./kWh). Mining and combustion of fuel are major hotspots for coal power $(82 \%$ and $16 \%$, respectively). Mining releases a significant amount of metals, such as nickel, beryllium, cobalt and vanadium, that contribute to freshwater ecotoxicity. Vanadium and beryllium are also released from the ash. For gas and oil, the main hotspot is plant decommissioning (37\% and $45 \%$, respectively) because of the release of copper during the scrap disposal.

\subsubsection{Global warming potential (GWP)}

Electricity from coal emits $1036 \mathrm{~g} \mathrm{CO}_{2}$ eq./kWh, while for oil and gas the GWP is equal to 868 and $646 \mathrm{~g} \mathrm{CO}_{2}$ eq./kWh, respectively. $\mathrm{CO}_{2}$ emissions account for $98 \%$ of the total GHGs emitted along the life cycle of the three options. Combustion of fuels is the main hotspot with a contribution of $95 \%$ for coal, $86 \%$ for oil and $76 \%$ for gas. In the gas life cycle, extraction and transport of LNG contribute together $23 \%$ of the impact, for which $\mathrm{CO}_{2}$ is again the main GHG. $\mathrm{CO}_{2}$ is emitted by machinery used for the extraction of gas, by compressors for its liquefaction and for transportation and refrigeration of LNG.

\subsubsection{Human toxicity potential (HTP)}

This impact is four times higher for coal (393 $\mathrm{g}$ DCB eq./kWh) than for oil (97 $\mathrm{g}$ DCB eq. $/ \mathrm{kWh}$ ) and nearly nine times greater than for gas power (46 g DCB eq./kWh). The combustion of fuel makes a large contribution for all three options: $82 \%$ for gas, $57 \%$ for coal and $36 \%$ for oil. In the case of coal combustion, the main contributor is the emission of hydrogen fluoride to the air and vanadium and thallium to freshwater from ash. For oil and gas, the emission of polycyclic aromatic hydrocarbons (PAH) is the main contributor to HTP.

\subsubsection{Marine aquatic ecotoxicity potential (MAETP)}

The MAETP for coal power is estimated at $2407 \mathrm{~kg}$ DCB eq. $/ \mathrm{kWh}$, which is 44 times higher than for oil power (55 kg DCB eq./kWh) and 174 times greater than for gas $(14 \mathrm{~kg}$ DCB eq./kWh). This is largely due to the combustion of coal $(76 \%)$, related to air emissions of hydrogen fluoride. The rest of the impact from coal power is attributed to coal extraction, associated with beryllium released to freshwater. On the other hand, the impact from oil and gas power is distributed quite evenly across the life cycle stages, except for the combustion of fuels, which has a negligible contribution. 


\subsubsection{Ozone layer depletion (ODP)}

For this category, oil power has the highest impact (108 $\mu \mathrm{g} \mathrm{R} 11$ eq./kWh), which is eight times larger than that of coal $(13 \mu \mathrm{g}$ R11 eq. $/ \mathrm{kWh})$ and two orders of magnitude worse than for gas $(1 \mu \mathrm{g} \mathrm{R} 11 \mathrm{eq} . / \mathrm{kWh})$. Fuel extraction has the highest contribution across the options: $91 \%$ for oil, $73 \%$ for coal and $45 \%$ for gas. Transport is the second most significant stage, with respective contributions of 5\%,22\% and 38\%. Oil production and transportation involve the use of fire suppressants, such as halon 1301, which is a major contributor in this case. It should be noted, however, that this introduces some uncertainty since the Montreal Protocol covers the use of halons and has led to their elimination in many sectors and regions (UNEP Ozone Secretariat, 2010). However, certain critical uses in the petrochemical industry are granted exemption, thus the actual use of halons will vary from country to country and between businesses. A similar situation applies to the transport of natural gas through longdistance pipeline in which halogenated compounds may be used as coolant for compressors, leading to higher ODP when gas is piped over large distances. In previous years natural gas was supplied in Chile via long-distance pipeline from Argentina and, therefore, potentially incurred high ODP, whereas nowadays gas is just supplied by tanker as LNG. If natural gas supplies once again came from Argentina, the ODP of gas power would increase from $1 \mu \mathrm{g}$ to $15.2 \mu \mathrm{g}$ R11 eq./kWh; higher than coal, but still lower than oil. It should also be noted that the ODP of coal power is increased due to the high ODP of petroleum coke, which contributes $4 \%$ to the electricity supply in Chile.

\subsubsection{Photochemical oxidants creation potential (POCP)}

The POCP of electricity from oil and coal is estimated at 420 and $320 \mathrm{mg} \mathrm{C}_{2} \mathrm{H}_{4}$ eq./kWh, respectively, while for gas power, the impact is equivalent to $83 \mathrm{mg} \mathrm{C}_{2} \mathrm{H}_{2}$ eq. $/ \mathrm{kWh}$. Combustion of fuels is the main source, contributing $63 \%$ for oil, $70 \%$ for coal and $47 \%$ for gas power, largely due to $\mathrm{NO}_{\mathrm{x}}$ and $\mathrm{SO}_{2}$ emissions. However, emissions of non-methane volatile organic compounds in diesel engine plants contribute to oil power being the worst option.

\subsubsection{Terrestrial ecotoxicity potential (TETP)}

Electricity from coal has a TETP of $2.2 \mathrm{~g}$ DCB eq./kWh, three times larger than oil $(0.8 \mathrm{~g})$ and seven times above gas $(0.3 \mathrm{~g})$. Combustion causes $85 \%$ of the impact for coal power, while extraction is the main life cycle stage for oil and gas, with a contribution of $47 \%$ and $40 \%$, respectively (without the system credits). Another stage with a significant contribution for gas and oil is construction of power plants and fuel reprocessing installations $(22 \%$ and $25 \%$ ). Heavy metals released to air are the main burdens across the options. For coal power, heavy metals present in coal are released during its combustion; for oil and gas power, they are emitted in the production of the steel used for infrastructure and machinery. However, recycling of steel and other end-of-life materials has only a small benefit for oil and gas power, reducing the impact by $16 \%$ in both options. Coal power is not affected by recycling because the contribution of the construction stage is very small $(1 \%)$.

\subsubsection{Comparison of results with literature}

The impacts obtained in this study have been compared to values in literature to validate the results and to identify any differences. As mentioned in the introduction, there are no other studies focusing on fossil-based electricity in Chile. Instead, the comparison here is with the impacts of individual fossil-fuel options estimated for other regions, including European countries, the US, Japan, Mexico and Turkey (Atilgan and Azapagic, 2015; Ecoinvent, 2010; Santoyo-Castelazo et al., 2011; Stamford and Azapagic, 2012). Only those values that have been estimated using the same impact assessment method used in this study (CML) are considered. 


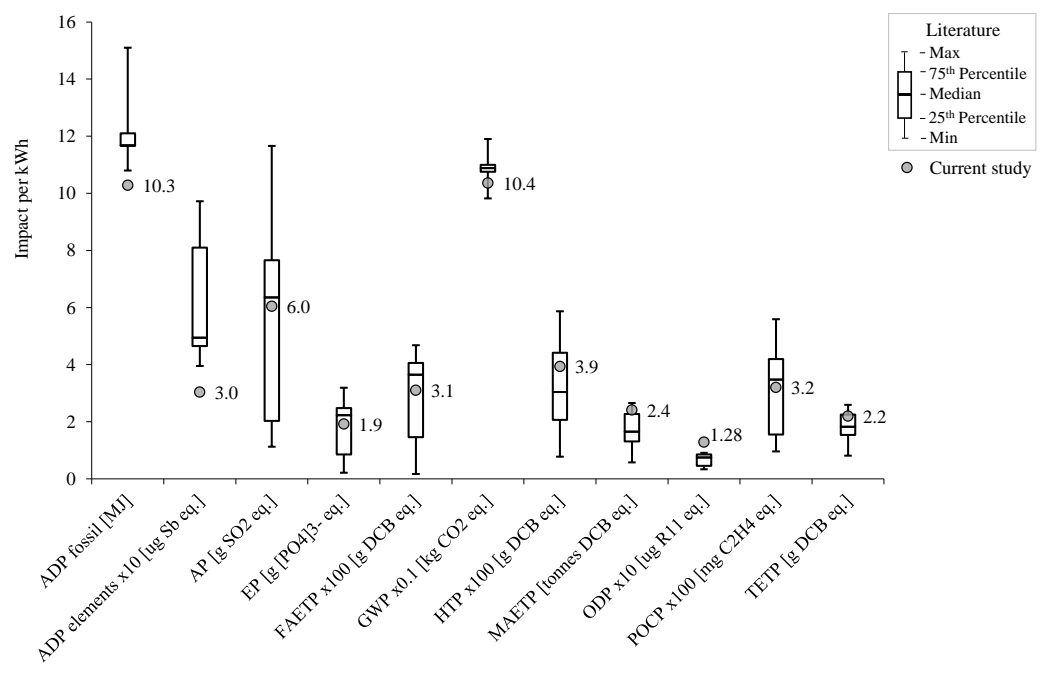

(a) Coal power

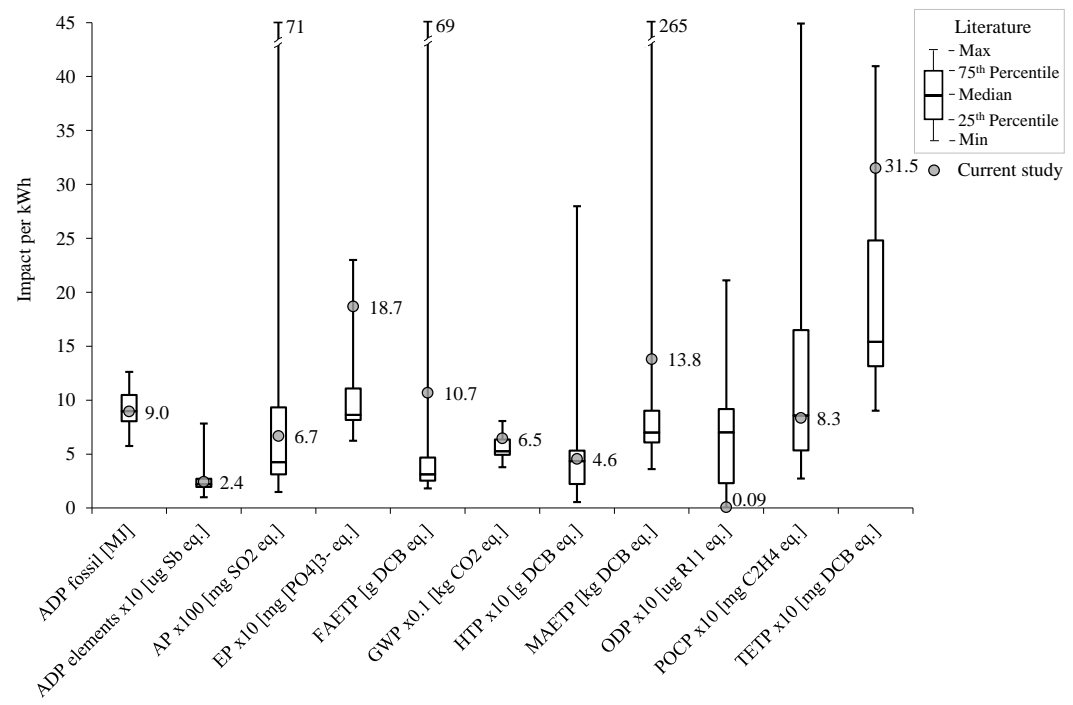

(b) Gas power

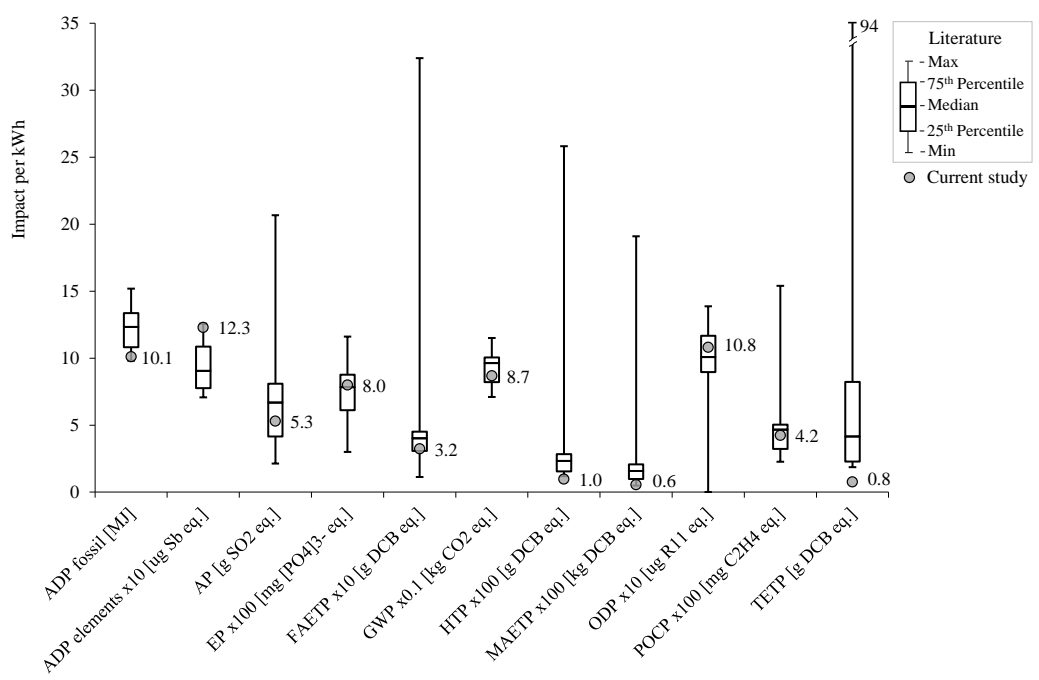

(c) Oil power

Figure 5. Comparison of the results from the current study with the literature for coal, gas and oil power. [Literature data sourced from (Atilgan and Azapagic, 2015; Ecoinvent, 2010; Santoyo-Castelazo et al., 2011; Stamford and Azapagic, 2012). The results for the current study are for the base year (2014) while the literature data span the period 20042014. The capacity factors and efficiencies vary across the literature. For the impacts nomenclature, see Figure 4] 
As can be seen in Figure 5, most of the results fall within the ranges found in the literature. An exception is ODP for coal power which is higher than elsewhere. As mentioned earlier, this is related to the high ODP of petroleum coke. On the other hand, the ODP of gas is lower than in the literature. This is due to the absence of long-distance pipelines for the transport of gas and the associated use of halogenated compounds (Schori and Frischknecht, 2012) since Chile uses LNG.

Two other impacts from coal also fall outside the literature ranges - depletion of fossil fuels and elements - both of which are lower than in the literature. This is because coal used in Chile has higher calorific value than elsewhere, together with greater efficiency of power plants and capacity factors (Ecoinvent, 2010).

For oil, HTP, MAETP and TETP are below the literature ranges. This is mainly a result of the higher efficiency of combined cycle power plants, which generate $73 \%$ of total power from oil in Chile, while other countries typically use diesel engines which have lower efficiency.

\subsection{Change in impacts over time}

This section discusses how the impacts of fossil-based electricity generated in the ten-year period from 2004 to 2014 have changed over the years and why. Both per-kWh and total annual impacts are considered. For the base year (2014), these have been estimated based on the impacts per $\mathrm{kWh}$ discussed in the previous sections and the contribution of each technology to the total generation (Table 6). For the previous years, the detailed analysis carried out for the base year has not been possible due to a lack of data. Instead, the data used in the base year have been combined with the data in Table 6 to estimate first the impacts of individual technologies and then their total annual impacts based on the amount of electricity they generated in those years.

As shown in Figure 6, the year 2014 exhibited the highest per-kWh impacts for six and the year 2009 for five impacts. Most of the impacts were lowest in 2004. The latter is due to a major contribution $(65 \%)$ of gas and lower share of coal $(35 \%)$ than in the other two years. Nonetheless, $32 \%$ of coal came from Australia which has a higher FAETP, leading to a worse outcome in 2004 than in 2009 for this indicator. Furthermore, 2004 experienced a peak in gas imports from Argentina, which was transported by long-distance pipelines, causing a higher ODP than in 2014. The subsequent lack of natural gas in 2009 resulted in an increase in oil electricity, together with a slight rise in coal power. Consequently, 2009 saw the highest per$\mathrm{kWh} \mathrm{ADP}_{\text {fossil }}, \mathrm{ADP}_{\text {elements, }}$ AP, ODP and POCP. In 2014, coal had a higher contribution than in the previous years, increasing EP, FAETP, GWP, HTP, MAETP and TETP.

Along with the FAETP improvement from 2004 to 2009, as stated above, in the next five-year

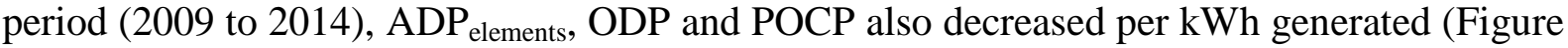
$6 \mathrm{c}, \mathrm{j}$ and $\mathrm{k}$ ). This is due to the reduced contribution of oil power from $33 \%$ to $7 \%$ over the period. It can be noticed that the first two impacts reduced by a higher rate than POCP because they are several times higher for oil than coal and gas (see sections 3.1.2 and 3.1.9), while this difference in POCP is much lower (section 3.1.10).

In addition to the changes in electricity mix on a year-by-year basis, overall electricity consumption has increased steadily over the decade (CNE, 2015a; Corbo and Hurtado, 2014). This has led to an increase in annual impacts through the years, which can be seen in Figure 6 for eight impacts (ADP fossil, AP, EP, GWP, HTP, MAETP, POCP and TET). However, for $\mathrm{ADP}_{\text {elements }}$ and ODP, the year 2009 had the highest impacts per $\mathrm{kWh}$. Hence, despite total generation being higher in 2014, the annual impacts decreased compared to 2009. 


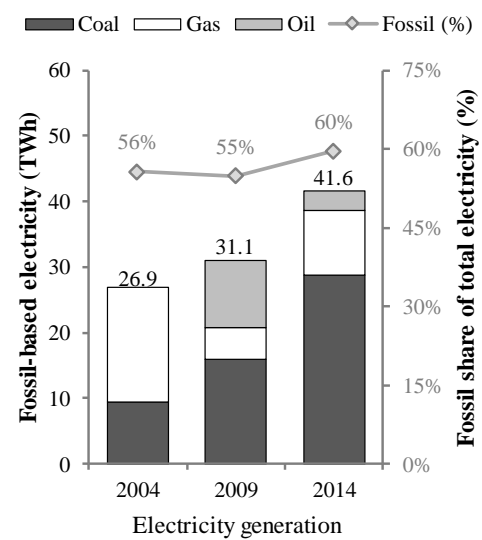

(a)

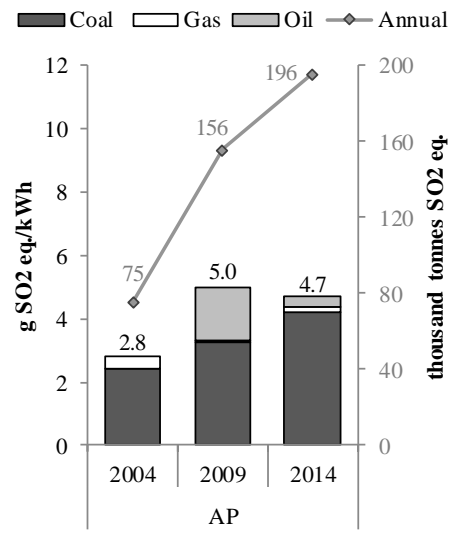

(d)

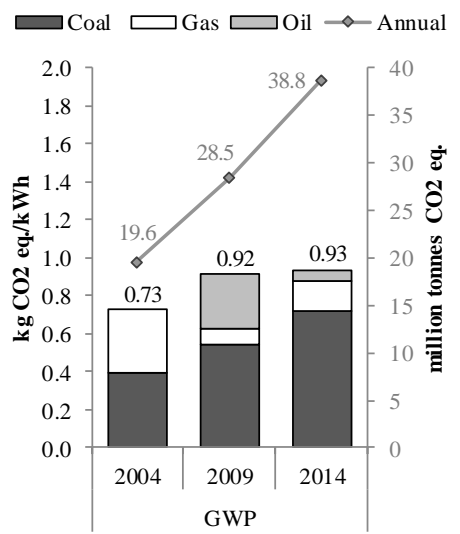

(g)

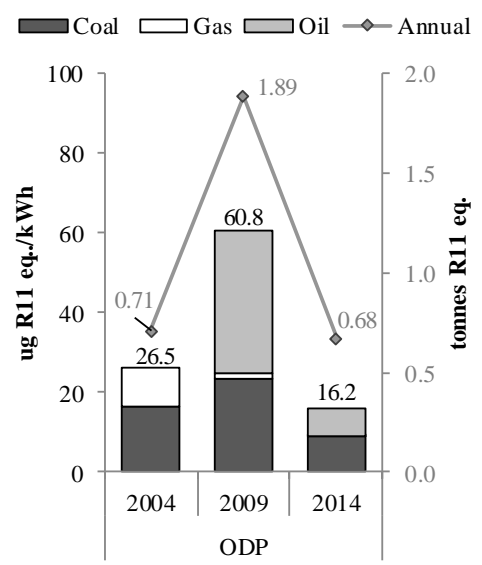

(j)

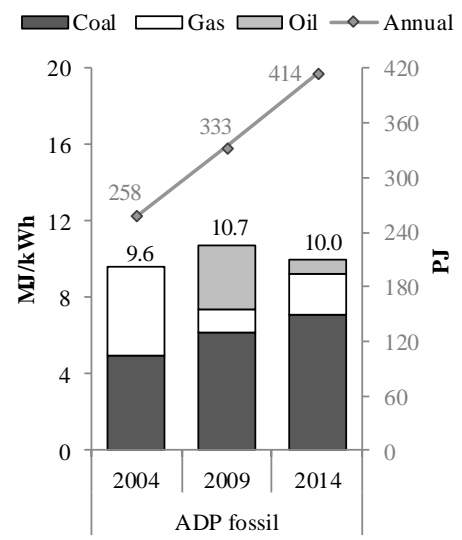

(b)

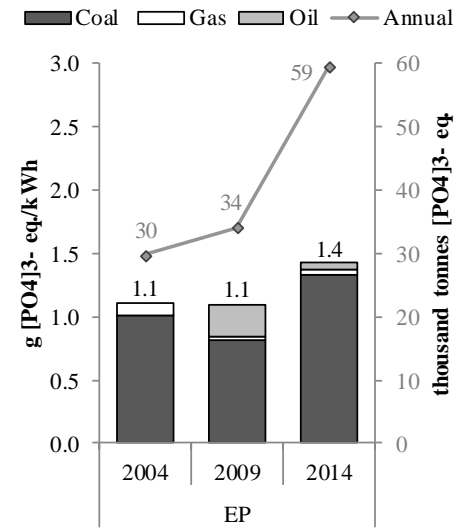

(e)

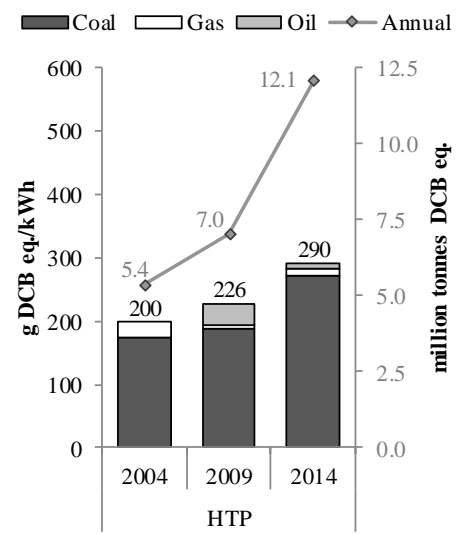

(h)

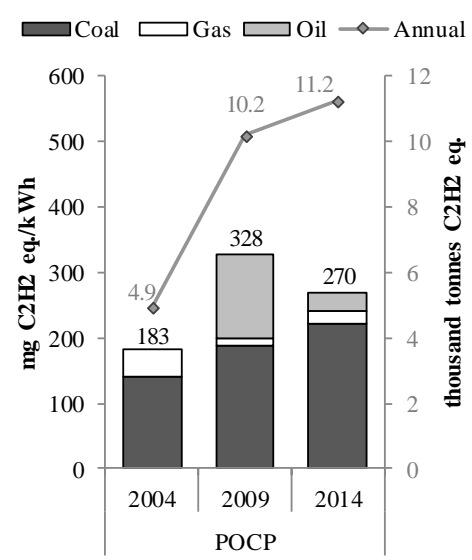

(k)

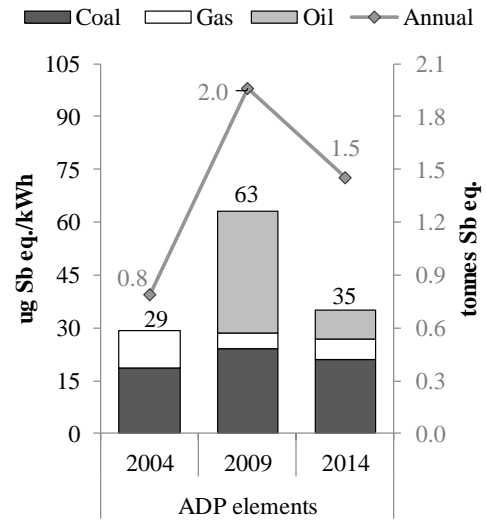

(c)

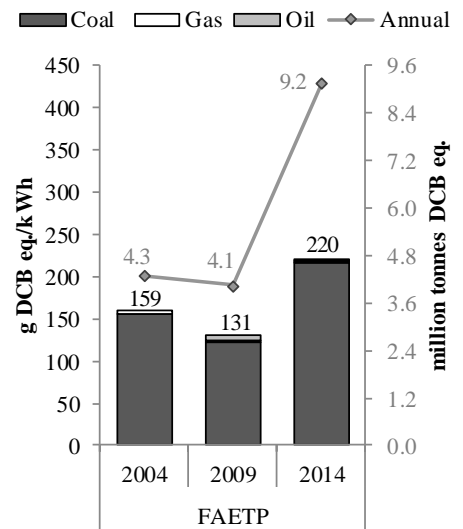

(f)

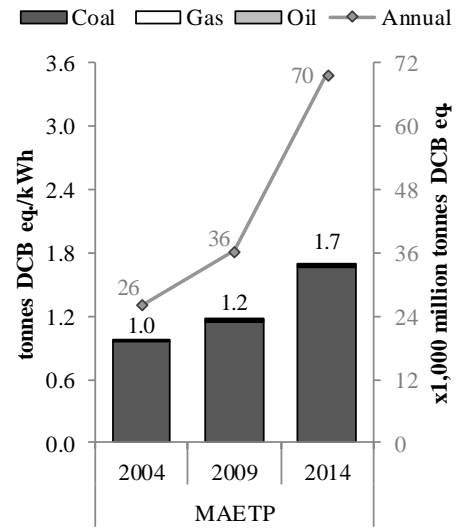

(i)

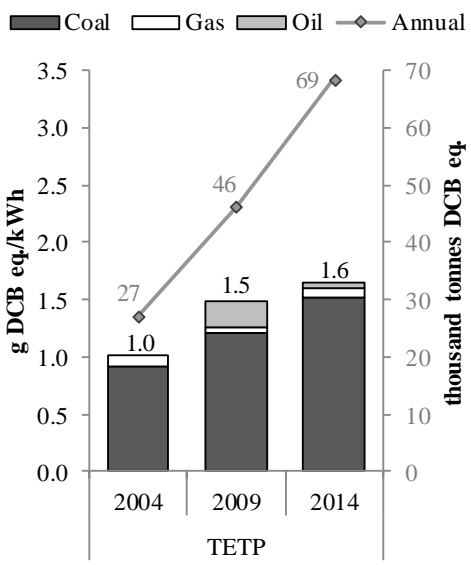

(I)

Figure 6. Environmental impacts of fossil-based electricity in Chile over the period 2004-2014.

[For impacts nomenclature, see Figure 4]. 
Overall, it can be seen that, while electricity generation increased by $55 \%$ during the last 10 years, the annual environmental impacts doubled on average in the same period. Only ODP decreased, by around 4\%, while the remaining ten impacts increased by between $60 \%$ $\left(\mathrm{ADP}_{\text {fossil }}\right)$ and 2.7 times (MAETP); the GWP doubled. It can also be observed from Figure 6 that the share of coal in the per-kWh impacts grew steadily over the years, in line with its share in the generation.

\section{CONCLUSIONS}

This study has estimated the environmental impacts of the fossil-based electricity generation in Chile and their evolution over a period of ten years, from 2004 to 2014.

Considering individual technologies, the results demonstrate that electricity from gas has the lowest impacts for all 11 impact categories considered. By contrast, coal power shows the worst performance for eight categories, with EP, FAETP and MAETP being between ten and 240 times greater than for gas. The impacts of oil power are typically in between, with three impacts higher than coal (POCP, $\mathrm{ADP}_{\text {elements }}$ and $\mathrm{ODP}$ ).

In terms of life cycle stages, operation of power plants is the main hotspot for AP, GWP, HTP, MAETP, POCP and TETP. Extraction of fuels also plays a major role for ADP $\mathrm{Alements}_{\text {, }}$ ADP fossil, FAETP and ODP. Construction of power plants is significant for $\mathrm{ADP}_{\text {elements }}$ of oil and gas power, but recycling of copper and steel helps to reduce those impacts by up to $21 \%$. Finally, transport and processing of fuels typically have a minor contribution.

When fossil-fuel electricity mix is considered over the years, six per-kWh impacts were highest in 2014 and five in 2009. Year 2004 had the lowest values for eight impact categories, exceeding 2009 only in EP and FAETP, and 2014 in ODP.

In terms of total annual impacts, an increase in ten environmental impacts can be seen from 2004 to 2014. This deterioration of environmental performance is mostly caused by the rise in the share of coal power, leading on average to the doubling of impacts over the period, despite an increase in electricity demand of only $55 \%$.

The worsening of environmental impacts over time runs contrary to the goals of sustainable development as well as against government targets for reducing GHG emissions by 2030 and should be addressed through appropriate policies. Based on the results of this work, policy in the short-term future should aim to:

- increase the efficiency of all power plants;

- prioritise coal consumption from mines with lower environmental impacts, such as those in South America, and avoid the use of petroleum coke;

- improve measures for emissions control not only for power plants but also across the life cycle, including copper and steel production and ash disposal; and

- displace coal and oil with gas power as soon as possible.

In the medium term to longer terms, it is critical to evaluate and broaden the deployment of renewable power technologies and possibly carbon capture and storage. The potential role of nuclear power could also be explored.

In addition to informing policy and the power industry, this work also fills the LCA data gap with respect to fossil-fuel electricity in Chile, required by LCA practitioners when assessing the environmental impacts of other products and services.

\section{ACKNOWLEDGMENTS}

The authors thank the Chilean Government for awarding to Carlos Gaete the scholarship "Becas Chile" for his doctoral study at The University of Manchester. 


\section{APPENDIX}

\section{A1. Data for oil power plants}

Table A1. Oil power plants in Chile in the base year.

\begin{tabular}{|c|c|c|c|c|c|c|c|}
\hline & Power plant & Type $^{\mathrm{a}}$ & Emission control systems ${ }^{\mathrm{b}}$ & $\begin{array}{c}\text { Installed } \\
\text { capacity (MW) }\end{array}$ & $\begin{array}{c}\text { Electricity in } 2014 \\
(\mathrm{GWh})\end{array}$ & $\begin{array}{c}\text { Share } \\
(\%)\end{array}$ & Efficiency $^{\mathrm{c}}(\%)$ \\
\hline 1. & Gas Atacama 1 & $\mathrm{CC}$ & LowNOx & 389 & 320 & $12 \%$ & $41 \%$ \\
\hline 2. & Gas Atacama 2 & $\mathrm{CC}$ & LowNOx & 383 & 558 & $20 \%$ & $42 \%$ \\
\hline 3. & San Isidro I & $\mathrm{CC}$ & - & 379 & 21 & $1 \%$ & $43 \%$ \\
\hline 4. & San Isidro II & $\mathrm{CC}$ & - & 399 & 39 & $1 \%$ & $46 \%$ \\
\hline 5. & Nueva Renca & $\mathrm{CC}$ & SCR & 379 & 725 & $26 \%$ & $46 \%$ \\
\hline 6. & Nehuenco I & $\mathrm{CC}$ & Wet scrubber & 368 & 233 & $8 \%$ & $50 \%$ \\
\hline 7. & Nehuenco II & $\mathrm{CC}$ & Wet scrubber & 398 & 107 & $4 \%$ & $50 \%$ \\
\hline 8. & Nehuenco III & $\mathrm{OC}$ & Wet scrubber & 108 & 5 & $<1 \%$ & $29 \%$ \\
\hline 9. & Taltal 1 & $\mathrm{OC}$ & - & 123 & 7 & $<1 \%$ & $31 \%$ \\
\hline 10. & Taltal 2 & $\mathrm{OC}$ & - & 122 & 1 & $<1 \%$ & $31 \%$ \\
\hline 11. & Candelaria 1 & $\mathrm{OC}$ & Wet scrubber & 136 & 7 & $<1 \%$ & $29 \%$ \\
\hline 12. & Candelaria 2 & $\mathrm{OC}$ & Wet scrubber & 136 & 6 & $<1 \%$ & $29 \%$ \\
\hline 13. & Santa Lidia & $\mathrm{OC}$ & - & 139 & $<1$ & $<1 \%$ & \\
\hline 14. & Los Vientos & $\mathrm{OC}$ & - & 132 & 10 & $<1 \%$ & \\
\hline 15. & Los Pinos & $\mathrm{OC}$ & - & 104 & 130 & $5 \%$ & \\
\hline 16. & Antilhue & $\mathrm{OC}$ & - & 103 & 60 & $2 \%$ & \\
\hline 17. & Emelda & $\mathrm{OC}$ & - & 69 & $<1$ & $<1 \%$ & \\
\hline 18. & Colmito & $\mathrm{OC}$ & - & 58 & 6 & $<1 \%$ & \\
\hline 19. & Huasco & $\mathrm{OC}$ & - & 58 & 1 & $<1 \%$ & \\
\hline 20. & SL de D. de Almagro & $\mathrm{OC}$ & - & 56 & $<1$ & $<1 \%$ & \\
\hline 21. & D. de Almagro & $\mathrm{OC}$ & - & 24 & $<1$ & $<1 \%$ & \\
\hline 22. & Yungay 1 & $\mathrm{OC}$ & - & 54 & $<1$ & $<1 \%$ & \\
\hline 23. & Yungay 2 & $\mathrm{OC}$ & - & 54 & $<1$ & $<1 \%$ & \\
\hline 24. & Yungay 4 & $\mathrm{OC}$ & - & 57 & $<1$ & $<1 \%$ & \\
\hline 25. & Coronel & $\mathrm{OC}$ & - & 47 & 23 & $1 \%$ & $35 \%$ \\
\hline 26. & MIMB & $\mathrm{OC}$ & - & 29 & 13 & $<1 \%$ & \\
\hline 27. & San Fco. de Mostazal & $\mathrm{OC}$ & - & 26 & $<1$ & $<1 \%$ & \\
\hline 28. & CTTO TG1 & $\mathrm{OC}$ & - & 25 & 2 & $<1 \%$ & \\
\hline 29. & CTTO TG2 & $\mathrm{OC}$ & - & 25 & 2 & $<1 \%$ & \\
\hline 30. & CTTO TG3 & $\mathrm{OC}$ & - & 38 & 11 & $<1 \%$ & \\
\hline 31. & TGTAR & $\mathrm{OC}$ & - & 24 & 6 & $<1 \%$ & \\
\hline 32. & El Salvador & $\mathrm{OC}$ & - & 24 & $<1$ & $<1 \%$ & \\
\hline 33. & TGIQ & $\mathrm{OC}$ & - & 24 & 6 & $<1 \%$ & \\
\hline 34. & Colihues & $\mathrm{OC}$ & - & 22 & 32 & $1 \%$ & \\
\hline 35. & Punta Colorada & $\mathrm{OC}$ & - & 17 & 23 & $1 \%$ & \\
\hline 36. & Cem Bio Bio & $\mathrm{OC}$ & - & 14 & 27 & $1 \%$ & \\
\hline 37. & Los Espinos & DE & - & 124 & 45 & $2 \%$ & \\
\hline 38. & Olivos & $\mathrm{DE}$ & - & 115 & 7 & $<1 \%$ & \\
\hline 39. & SUTA & DE & - & 104 & 173 & $6 \%$ & \\
\hline 40. & El Peñón & $\mathrm{DE}$ & - & 90 & 64 & $2 \%$ & \\
\hline 41. & Termopacífico & $\mathrm{DE}$ & - & 81 & 3 & $<1 \%$ & \\
\hline 42. & Trapén & $\mathrm{DE}$ & - & 81 & 26 & $1 \%$ & \\
\hline 43. & Teno & $\mathrm{DE}$ & - & 59 & 12 & $<1 \%$ & \\
\hline 44. & Degañ & $\mathrm{DE}$ & - & 36 & $<1$ & $<1 \%$ & \\
\hline 45. & Chuyaca & $\mathrm{DE}$ & - & 15 & 2 & $<1 \%$ & \\
\hline 46. & CalleCalle & $\mathrm{DE}$ & - & 13 & 3 & $<1 \%$ & \\
\hline 47. & Constitución & $\mathrm{DE}$ & - & 9 & 2 & $<1 \%$ & \\
\hline 48. & GMAR & $\mathrm{DE}$ & - & 8 & 7 & $<1 \%$ & \\
\hline 49. & Quellón II & $\mathrm{DE}$ & - & 8 & 2 & $<1 \%$ & \\
\hline 50. & INACAL & $\mathrm{DE}$ & - & 7 & 8 & $<1 \%$ & \\
\hline 51. & Maule & $\mathrm{DE}$ & - & 6 & 1 & $<1 \%$ & \\
\hline 52. & ZOFRI_2-5 & $\mathrm{DE}$ & - & 5 & 3 & $<1 \%$ & \\
\hline 53. & ZOFRI_7-12 & $\mathrm{DE}$ & - & 5 & 4 & $<1 \%$ & \\
\hline 54. & SUIQ & DE & - & 4 & 2 & $<1 \%$ & $36 \%$ \\
\hline 55. & Lebu & $\mathrm{DE}$ & - & 4 & $<1$ & $<1 \%$ & \\
\hline 56. & Cañete & $\mathrm{DE}$ & - & 3 & $<1$ & $<1 \%$ & \\
\hline 57. & El Totoral & $\mathrm{DE}$ & - & 3 & $<1$ & $<1 \%$ & \\
\hline 58. & Estancilla & $\mathrm{DE}$ & - & 3 & $<1$ & $<1 \%$ & \\
\hline 59. & Placilla & $\mathrm{DE}$ & - & 3 & $<1$ & $<1 \%$ & \\
\hline 60. & Quintay & $\mathrm{DE}$ & - & 3 & $<1$ & $<1 \%$ & \\
\hline 61. & Curacautín & $\mathrm{DE}$ & - & 3 & 1 & $<1 \%$ & \\
\hline 62. & Curauma & $\mathrm{DE}$ & - & 3 & $<1$ & $<1 \%$ & \\
\hline 63. & Eagon & $\mathrm{DE}$ & - & 2 & 1 & $<1 \%$ & \\
\hline 64. & Trongol-Curanilahue & $\mathrm{DE}$ & - & 2 & $<1$ & $<1 \%$ & \\
\hline 65. & Concón & DE & - & 2 & $<1$ & $<1 \%$ & \\
\hline 66. & Las Vegas & $\mathrm{DE}$ & - & 2 & $<1$ & $<1 \%$ & \\
\hline 67. & Lonquimay & $\mathrm{DE}$ & - & 2 & $<1$ & $<1 \%$ & \\
\hline 68. & Los Sauces I & $\mathrm{DE}$ & - & 2 & 1 & $<1 \%$ & \\
\hline 69. & Los Sauces II & $\mathrm{DE}$ & - & 2 & $<1$ & $<1 \%$ & \\
\hline 70. & Contulmo & $\mathrm{DE}$ & - & 1 & $<1$ & $<1 \%$ & \\
\hline 71. & San Gregorio & $\mathrm{DE}$ & - & 1 & $<1$ & $<1 \%$ & \\
\hline
\end{tabular}
reduction. ${ }^{\circ}$ Efficiency of OC plants no. 13-36 and DE no. 37-71 determined from electricity produced and fuel consumed. 


\section{A2. Estimation of capacity factors and environmental burdens}

The capacity factors are estimated as follows:

$$
C F_{\text {actual }}=\frac{E}{8760 P}
$$

where:

$C F_{\text {actual }}$ capacity factor of a plant of interest (-)

$E \quad$ electricity generated per year $\left(\frac{M W h}{y r}\right)$

$P \quad$ installed capacity $(M W)$

8760 number of hours in a year.

The infrastructure-related environmental burdens of each plant are then estimated based on the burdens of the reference plant in Ecoinvent (400 MW) as follows:

$B_{\text {actual }}=\frac{B_{\text {ref }}}{8760 P_{\text {ref }} C F_{\text {actual }} L_{\text {actual }}} \quad\left(\frac{\text { unit }}{M W h}\right)$

where:

$B_{\text {actual }}$ environmental burden of a power plant of interest (burden/unit)

$B_{\text {ref }} \quad$ environmental burden of a reference power plant in Ecoinvent (burden/unit)

$P_{\text {ref }} \quad$ installed capacity of the Ecoinvent reference power plant (MW)

$C F_{\text {atual }}$ capacity factor of a power plant of interest (-)

$L_{\text {atual }}$ lifespan of a power plant of interest $(y r)$.

\section{REFERENCES}

Atilgan, B., Azapagic, A., 2015. Life cycle environmental impacts of electricity from fossil fuels in Turkey. J. Clean. Prod. 106, 555-564. https://doi.org/10.1016/j.jclepro.2014.07.046

Bartos, J., Robertson, A., 2014. Energy Supply Security: Emergency Response of IEA Countries. Int. Energy Agency 606.

Bronfman, N.C., Jiménez, R.B., Arévalo, P.C., Cifuentes, L.A., 2012. Understanding social acceptance of electricity generation sources. Energy Policy 46, 246-252. https://doi.org/10.1016/j.enpol.2012.03.057.

CISEN, 2016. Updated database [WWW Document]. Indep. Coord. Natl. Electr. Syst. URL https://www.coordinador.cl/informes-y-documentos/ (accessed 5.5.16).

CNE, 2015a. Database of electricity generation in Chile [WWW Document]. Natl. Energy Comm. Chile. URL https://www.cne.cl/estadisticas/electricidad/ (accessed 5.5.15).

CNE, 2015b. Installed capacity in the SIC and SING [WWW Document]. Natl. Energy Comm. Chile. URL https://www.cne.cl/estadisticas (accessed 7.6.15).

CNE, 2015c. Hydrocarbons - Imports [WWW Document]. Natl. Energy Comm. Chile. URL https://www.cne.cl/estadisticas/hidrocarburo/ (accessed 5.1.15).

CNE, 2015d. Short-term nodal electricity price of the central interconnected electricity system - Final report (Fijación de precio de nudo de corto plazo del sistema interconectado central - Informe técnico definitivo), National Energy Commission of Chile. In Spanish.

CNE, 2015e. Short-term nodal electricity price of the interconnected electricity system of Norte Grande - Final report (Fijación de precio de nudo de corto plazo del sistema interconectado del Norte Grande - Informe técnico definitivo), National Energy Commission of Chile. In Spanish.

CNE, 2015f. Series of Average Market Price of the Interconnected Systems (Serie de Precio Medio de Mercado de Sistemas Interconectados), National Energy Commission of Chile. In Spanish.

CONAMA, 2010. First report of solid waste management in Chile (Primer reporte del manejo de residuos sólidos en Chile), Comisión Nacional del Medio Ambiente de Chile. In Spanish.

Corbo, V., Hurtado, A., 2014. Causes and consequences of the energy problem in Chile: A vision from the macroeconomy (Causas y consecuencias del problema energético en Chile: Una visión desde la macroeconomía), Puntos de Referencia - Centro de estudios publicos. In Spanish.

Dones, R., Bauer, C., Röder, A., 2007. Coal (Kohle), in: Dones, R., Bauer, C., Röder, A. (Eds.), Life Cycle Inventories of Energy Systems, Ecoinvent Report No. 6. Swiss Centre for Life Cycle 
Inventories. Dübendorf, CH. In German.

Ecoinvent, 2010. Ecoinvent V2.2 database. Swiss Centre for Life cycle Inventories [WWW Document]. URL https://www.ecoinvent.org/.

ENAP, 2015. Annual report 2014 (Memoria anual 2014), Empresa Nacional del Petroleo. In Spanish.

Gaete-Morales, C., Gallego-Schmid, A., Stamford, L., Azapagic, A., 2018. Assessing the environmental sustainability of electricity generation in Chile. Sci. Total Environ. 636, 11551170. https://doi.org/10.1016/j.scitotenv.2018.04.346.

Garcia, R., Marques, P., Freire, F., 2014. Life-cycle assessment of electricity in Portugal. Appl. Energy 134, 563-572. https://doi.org/10.1016/j.apenergy.2014.08.067.

Guinée, J.B., Gorree, M., Heijungs, R., Huppes, G., Kleijn, R., de Koning, A., van Oers, L., 2002. Handbook on life cycle assessment, Operational guide to the ISO standards. Ministry of Housing, Spatial Planning and Environment (VROM) and Centre of environmental Science (CML), The Hague and Leiden, The Netherlands. https://doi.org/10.1007/0-306-48055-7.

Hackley, P.C., Warwick, P., Alfaro, G., Cuebas, R., 2006. World coal quality inventory: Chile, in: Karlsen, A.W., Tewalt, S.J., Bragg, L.J., Finkelman, R.B. (Eds.), World Coal Quality Inventory: South America. U.S.Geological Survey, Fresno, California, p. 1241.

International Energy Agency, 2014. Key world energy statistics 2014, Statistics. https://doi.org/10.1787/9789264039537-en.

International Energy Agency, 2012. Oil and gas security Chile 2012, International Energy Agency. https://doi.org/10.3366/saj.2004.26.1-2.vi.

International Energy Agency, 2009. Chile energy policy review.

International Group of Liquefied Natural Gas Importers, 2015. The LNG industry in 2014.

International Institute for Sustainability Analysis and Strategy, 2015. Global emissions model for integrated systems (GEMIS).

International Organization for Standardization, 2006a. ISO 14040 - Environmental management - Life cycle assessment - Principles and framework. Geneva, Switzerland.

International Organization for Standardization, 2006b. ISO 14044 - Environmental management - Life cycle assessment - Requirements and guidelines. Geneva, Switzerland.

Jungbluth, N., 2007. Crude Oil (Erdöl), in: Dones, R. (Ed.), Life Cycle Inventories of Energy Systems, Ecoinvent Report No. 6. Swiss Centre for Life Cycle Inventories. Dübendorf, CH.

Ministry of Energy of Chile, 2015. Non-Conventional renewable energy summary report 2014 (Reporte ERNC resumen 2014). In Spanish.

Ministry of Energy of Chile, 2014a. Energy balance of Chile.

Ministry of Energy of Chile, 2014b. Energy agenda: A challenge for the country, progress for everyone.

Ministry of Energy of Chile, 2013. Law 20698. Chile.

Ministry of Environment of Chile, 2015. Intended Nationally Determined Contribution (INDC) of Chile: Towards the climate agreement of Paris.

Ministry of Environment of Chile, 2014. Chile's first biennial update report. Executive summary.

PE International, 2013. Life cycle assessment software (GaBi) Version 6.

Platts McGraw Hill Financial, 2015. Portworld distance calculator [WWW Document]. URL http://www.portworld.com/map (accessed 5.1.15).

PRIEN-UTFSM, 2008. Potential contribution of non-conventional renewable energy and energy efficiency to the electricity mix 2008-2025 (Aporte potencial de energías renovables no convencionales y eficiencia energética a la matriz electrica 2008 - 2025). In Spanish.

Raineri, R., 2006. Chile. Where it all started, in: Sioshansi, F.P., Pfaffenberger, W. (Eds.), Electricity Market Reform. Elsevier, UK, pp. 77-108. https://doi.org/10.1016/B978-008045030-8/50005-9.

Santana, C., Falvey, M., Ibarra, M., García, M., 2014. Renewable energy in Chile. The power potential of wind, solar and hydropower from Arica to Chiloe (Energías renovables en Chile. El potencial eólico, solar e hidroeléctrico de Arica a Chiloé), Ministry of Energy of Chile. Santiago, Chile. In Spanish.

Santoyo-Castelazo, E., Gujba, H., Azapagic, A., 2011. Life cycle assessment of electricity generation in Mexico. Energy 36, 1488-1499. https://doi.org/10.1016/j.energy.2011.01.018.

Schori, S., Frischknecht, R., 2012. Life Cycle Inventory of Natural Gas Supply. ESU-Services fair Consult. Sustain.

SEA, 2015. Environmental impact assessment system (Sistema de evaluación de impacto ambiental) [WWW Document]. Environ. Eval. Serv. URL http://www.sea.gob.cl/ (accessed 12.3.16). In 
Spanish.

SEA, 2011. Mina Invierno - Coal mine environmental impact study, Environmental Evaluation Service.

Sims, D., 2011. Chile's clean energy future, Natural Resources Defense Council.

SMA, 2015. Data record of emissions and fuel composition for Chilean thermal power plants, Environmental Protection Agency of Chile. Santiago, Chile.

Spielmann, M., Bauer, C., Dones, R., Tuchschmid, M., 2007. Transport Services, ecoinvent report No. 14. Swiss Centre for Life Cycle Inventories. Dübendorf, $\mathrm{CH}$.

Stamford, L., Azapagic, A., 2012. Life cycle sustainability assessment of electricity options for the UK. Int. J. Energy Res. 36, 1263-1290. https://doi.org/10.1002/er.2962.

Superintendencia de Electricidad y Combustibles de Chile, 2014. Fuels Statistic Report 2014 Chile (Informe estadistico de combustibles 2014 Chile). In Spanish.

UN Intergovernmental Panel on Climate Change, 2007. Mitigation of climate change: Contribution of working group III to the fourth assessment report of the Intergovernmental Panel on Climate Change, Intergovernmental Panel on Climate Change.

UNEP Ozone Secretariat, 2010. Handbook for the Montreal protocol on substances that deplete the ozone layer, The Montreal protocol, Summary of control measures under the Montreal protocol, Annex A - Group II: Halons (Halon 1211, Halon 1301 and Halon 2402).

Vega-Coloma, M., Zaror, C.A., 2018. Environmental impact profile of electricity generation in Chile: A baseline study over two decades. Renew. Sustain. Energy Rev. 94, 154-167. https://doi.org/10.1016/j.rser.2018.05.058. 